Historic, Archive Document

Do not assume content reflects current scientific knowledge, policies, or practices. 



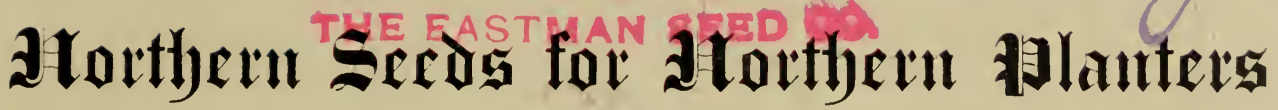

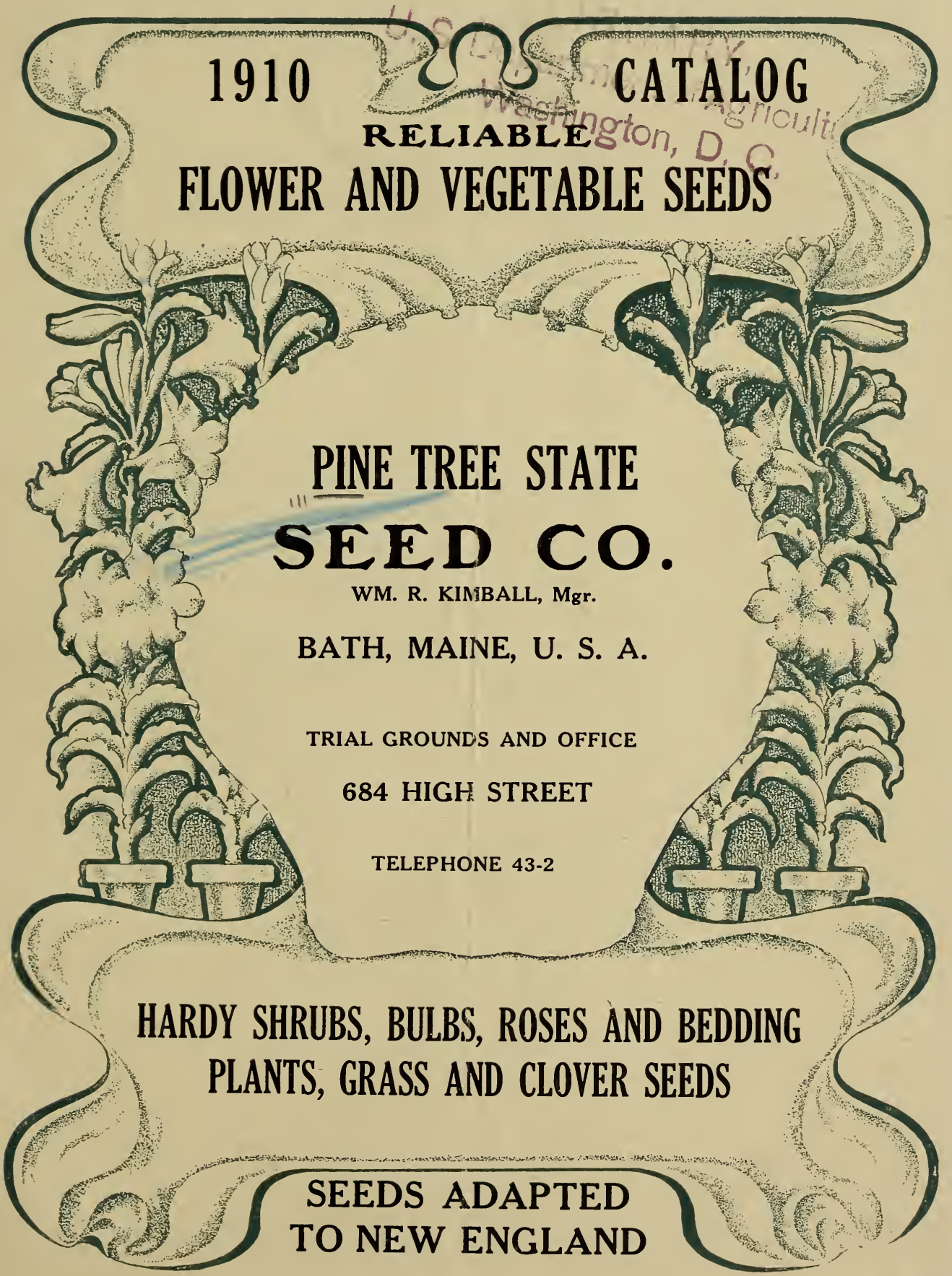

A. HALLET \& CO., 70 Front Street, Down-town Agents 


\section{FREE PREMIUMS.}

\section{FREE PREMIUM OFFER NO. 1}

By a special arrangement with The Phelps Publishing Co. of Fipringficld, Mass., publishers of the Farm and Hone, we offer you free a year's subscription to this fine paper, the most practical agricultural paper published anywhere.

We furnish this paper only upon request and when (ash accompanies the order.

\section{Read Carefully the Conditions.}

To anyone purchasing $\$ 2.00$ worth or more of seed by the packet, ounce, quart or pound, we will send them the paper FREE for one year.

\section{FREE PREMIUM OFFER NO. 2}

To anyone purchasing $\$ 3.00$ worth or more of seed we will send them the Farm and Fireside free for one year, upon request, and when cash accompanies the order.

This great National Farm paper is published by The Crowell Publishing Co. semimonthly, and we are glad to be able to offer so fine a paper to our customers.

\section{FREE PREMIUM OFFER NO. 3}

To anyone purchasing $\$ 5.00$ worth or more of seeds at catalog prices and for cash, we will upon request send them an "Old Reliable" Dietz Lantern. This lantern is much superior" to the common kind usually sold. Safe and convenient and gives the brightest light.

\section{FREE PREMIUM OFFER NO. 4}

To anyone purchasing $\$ 7.00$ worth or more of seeds at catalog prices and for cash, we will send them a Fine Pocket Knife. These knives are made by the Robeson Cutlery Co., of Rochester. Two blades of best high tempered steel, stag handle and fincly finished. Known as the Easy Opener Knife.

\section{IMPORTANT ANNOUNCEMENT}

We are pleased to announce that we have purchased the mail order business of the Eastman Seed Co. of East Sumner and have arranged with Mr. WV. H. Eastman, the manager, to carry a full supply of his exclusive specialties, and he will continue to grow for us his leading novelties and specialtics and thus maintain the high standard of the "Eastman grown" stock. They are cspecially adapted to our New England climate and soil.

\section{LEST YOU FORGET}

Do not neglect to include in your order, even if only a small quantity, the following, our stocks of which are exceptionally fine:

Low's Champion Bush Beans

('rimson Globe Beet

Golden Bantam Corn

Davis Perfect ('uremubrer

Beefisteak Lettuce

Yellow (ilobe Inanvers Onion

Yankee Watermelon

Sutton's Excelsior Pea

Winter Luxury Pumpkin Icicle Radish Delieious Syuash

Try our Sweet Peas and Nasturtiums, our mixtures contain all the known varieties.

Farmers should subscribe for the

\section{PORTLAND DAILY PRESS}

as its market reports are carefully prepared and its daily price current will keep them posted in all changes in prices of produce. Its general news is also full and complete.

Send a quarter for a trial month. 


\section{Important Announcement.}

To the patrons of the EASTMAN SEED CO.:-

Having two years ago accepted the Oxford County agency of the Lnion Mutual Life Insurance Co, and wishing to devote my time more extensively to that business, I take pleasure in announcing that our mail order business will be continued by the

\section{Pine Tree State Seed Co., Bath, Maine.}

who will act as selling agents for our exclusive specialties, and carry a full line of general seed supplies. I shall, however, continue to crow the leading specialties our house has put out, and endeavor to maintain the high standard of the "Eastman grown" stock.

I take this opportunity to thank our customers of the past twenty-five years for their generous patronage, and bespeak for our successors a continuance of the same.

\section{Yours for good seeds,}

WELLINGTON H. EASTMAN.

\section{Eastman's Specialties. For I9ıo.}

\section{Bright and Early Tomato.}

Of the novelties we have introduced during the past twenty-five years, the greatest favorites have been the ones in which extreme earliness is one of the leading characteristics. Eastman's Early Sweet Corn, the Iightning Bean and the Granite State Musk Melon stand in evidence as striking examples, the demand for each increasing each year. The Bright and Early Tomato is no exception. We consider it the best combination of earliness, yield and quality yet attained in this vegetable, and where best known is the leading early tomato for home use and for early market. We have repeatedly tried it in comparison with the leading early varieties, and the BRIGHT AND EARLY has invariably been first to ripen. Extensive tests elsewhere point in the same direction. One market gardener reports that with him it was fully two weeks ahead of any other variety, over fifty kinds being tested. The form of the BRIGHT AND EARLY is nearly round, somewhat flattened with smooth surface, free from irregularities. Color is a deep, handsome red, very uniform in shade. The skin is firm and free from cracks, the flesh solid and of finest flavor. While some large specimens are produced, the average size is slightly below medium. But whatever is lacking in size of the individual fruit is more than made up in the immense clusters in which they are bourne. In ordinary field culture on an extensive scale they have yielded with us at the rate of over five hundred bushels of ripe fruit to the acre. Best re-

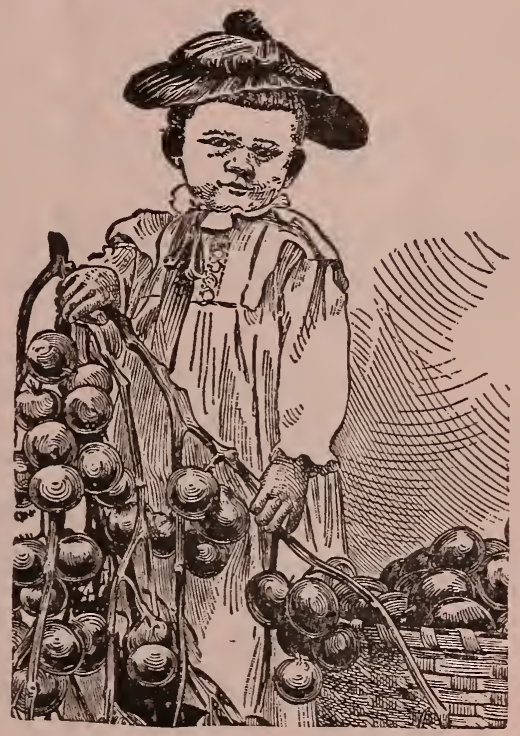

sults are obtained both in quality and quantity of yield, and especíally earliness, if high manuring is avoided.

$$
\text { Per oz. } 50 \text { cts., pkt. } 5 \text { cts. }
$$

Bright and Eahly, Extra Selecten From our field of seed tomatos, we each sea. son pick at the rate of four or five bushels t) the acre of earliest ripe fruit, the seeds of which should give a little better results in earliness than the general run of the crop. Per pkt. 10 cts. 


\section{Eastman's Early Sweet Corn.}

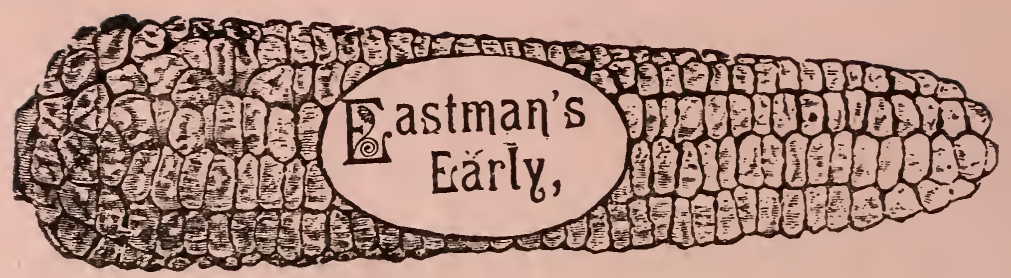

Eastman's Early Sweet Corn still holds the lead in earliness. Although every few years some new variety is offered that is claimed to be from a week to ten days ahead of anything else, when tested on our trial grounds they are invariably outstripped by Eastman's Early planted alongside. It is the finest flavored of the extra early varieties, and outyields every other early kind we have ever tested, two good ears on a stalk being common when it is given plenty of room. It has white kernels and a pure white cob. during all the years our customers have planted it we lo not recall a single unfavorable report, and the demand for it steadily increases. Our sales of Eastman's Early exceed that of all other varieties of sweet corn combined.

Per quart $45 \mathrm{cts}$. ( $30 \mathrm{cts}$. by express); pint $25 \mathrm{cts}$; pkt. $5 \mathrm{cts}$.

Eastman's Early, Extra Selected. It has always been our practice to go through our field of Eastman's Early each year and select the first and best ears for our own seed stock, thereby perpetuating and accentuating its leading characteristic of superlative earlinesss. The past few seasons we have made a little more thorough selection and harvest of the first-fruits, and offer at a slight advance in price to such of our customers as prefer to pay a little more for the probable gain of a few days in time of maturity. Per qt. 55 cts. ( $40 \mathrm{cts}$. by express); pint $30 \mathrm{cts}$; pkt. $10 \mathrm{cts}$.

WHAT OTHERS SAY OF IT.

At N. H. Experiment Station, in a field test of 41 varieties, Eastman's Early took the lead in earliness, yield and quality.

U.S. Department of Agriculture tests, conlucted at their Experiment Stations in Maine New Hampshire, Nebraska and Virginia, with Cory, Peep'O Day. Golden Bantam, etc. in comparison, EAsTMaN's EARLY led all other varieties in earliness.
Eden Trial Grounds, Raynham, Mass., Dec. 19, 1908. Your re-selected EAsTMAN's EARLY sweet corn is the earliest sweet corn, beating Peep 'O Day the last $t$ wo years by a week or more. It is a swEeT corn, also a heavy cropper, 3 to 5 ears on many stalks every year. I had every thing known in the sweet corn line for trial this year, but nothing proved as early as vours.

(Rev.) J. R. Lawrence.

\section{Eastman's Ideal Sweet Corn.}

Several years ago we started to originate a sweet corn to follow Fastman's Early. We desired something to be ready for the table as soon as that variety was past its prime, and to surpass it in every point except earliness. After repeated trials we attained the points sought for, and first offered our new creation in I 909, under the name of EASTMAN's IIEAL. The IDEAL closely follows Eastman's Early in point of maturity, possesses the siveetness of the Crosby, and is more prolific than either. The ears are twelve to sixteen rowed, of good size, and all that can be desired for quality. We predict for it a leading place as a market 'variety.

Per qt. 75 cts. (60 cts. by express); pt. 40 cts.; half-pt. $20 \mathrm{cts}$; pkt. $10 \mathrm{cts}$.

\section{Purity Cucumber.}

Starting with one of the tender foreign varieties of white cucumber, we spent sev eral years in improving and acclimating it until in 1900 we offered it under the name of PURITY. While pre-eminently an exhibition variety, it is in its early stages unsurpassed for the table, crisp, tender, of the mildest flavor, which we have never known to be tainted with the slightest hint of bitterness. We do not recommend it, however, for a general crop, but for limited family use and exhibition purposes. It is now thoroughly Americanized, and may be depended on under ordinary conditions to produce a crop of the fairest and purest cucumbers imaginable, many specimens from two feet upwards in length. No variety equals it for ripe cucumber sweet pickles. It has but few seeds, consequently must always be higher priced than the common sorts. 


\section{Lightning Bean.}

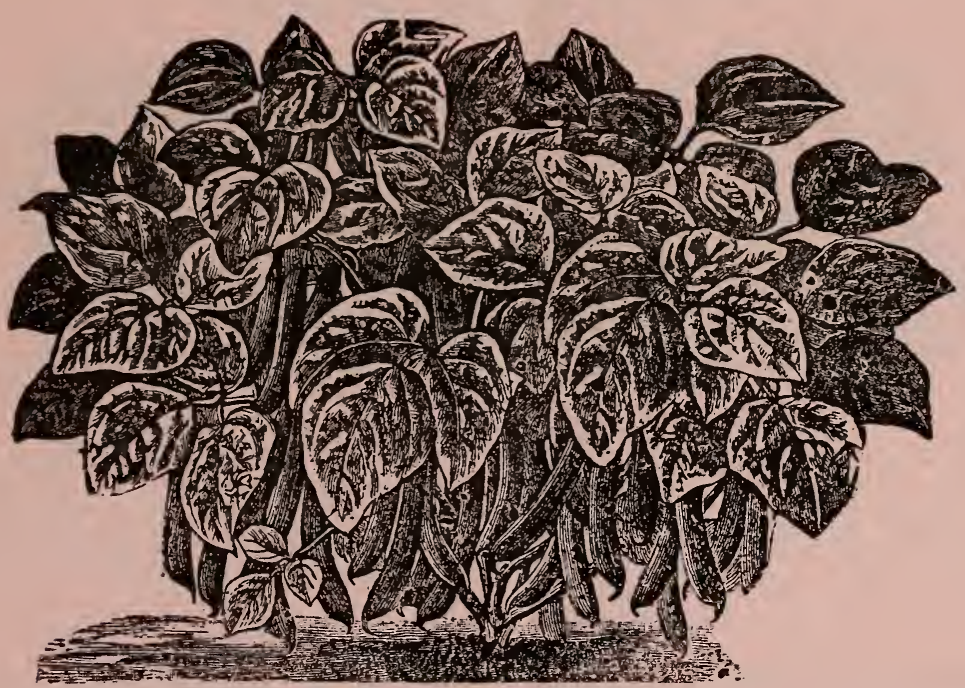

This earliest of all beans has proved one of our most satisfactory introductions. Sicle by side with other extra early varieties on our trial grounds, it has exceeded them in earliness in every instance. While not quite equaling Jack's fabulous bean stalk of the fairy tale, that grew up and blossomed in a night, it still needs to be closely watched when the beans begin to form, as a very few days from the blossom will give pods suitable for string heans. At this stage of their growth they are very tender and of rich flavor. But they ketp right on growing, and in a few days more the pods have toughened and not long after they are fit for shelling. It exactly resembles the old $F$ egee in appearance, but with us it has come into bearing fully two weeks ahead of that variety.

Per qt. 50 cts. (35 cts. by express); pint 25 cts.; pkt. ro cts.

\section{Metcalf Squash.}

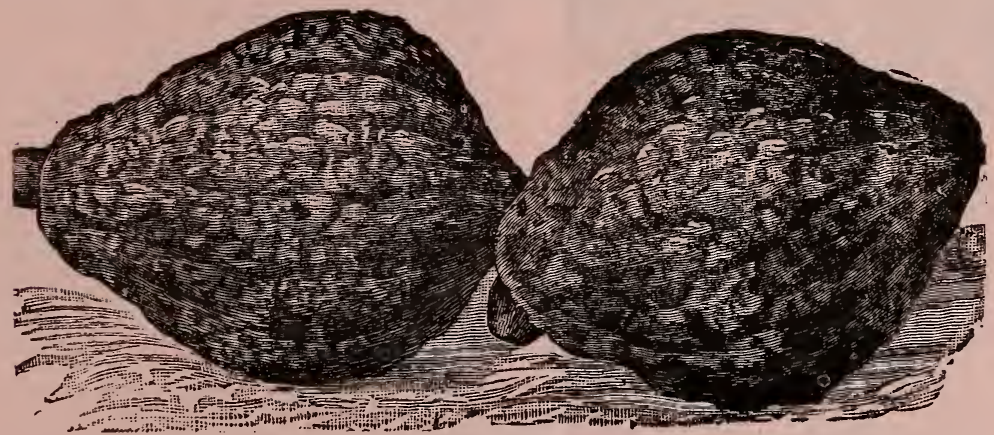

In yield the Metcalf outstrips every other variety of table squash. It has been fot years the local favorite in the vicinity of Lewiston, in this State, nearly driving other varities out of the markets of that city during the fall and early winter. It closely resembles the well known Boston Marrow, with the good points of that popular variety intensified; differing from it, however, in being more uniformly of a deep rich orange, in growing somewhat more irregular in shape, and in having, in many specimens, a decidedly rough exterior, and a somewhat thicker skin. It possesses all the characteristics of a good market variety for fall and early winter use, being productive, of good market size, and of supe: rior quality. The illustration is engraved form a photograph of two average specimens grown on our own grounds.

Per lb. $\$ \mathrm{r}: 00 \mathrm{r}=4$ lb. jo cts.; oz. ro cts. pkt. $5 \mathrm{cts}$. 


\section{Tattooed Yankee Pop Corn.}

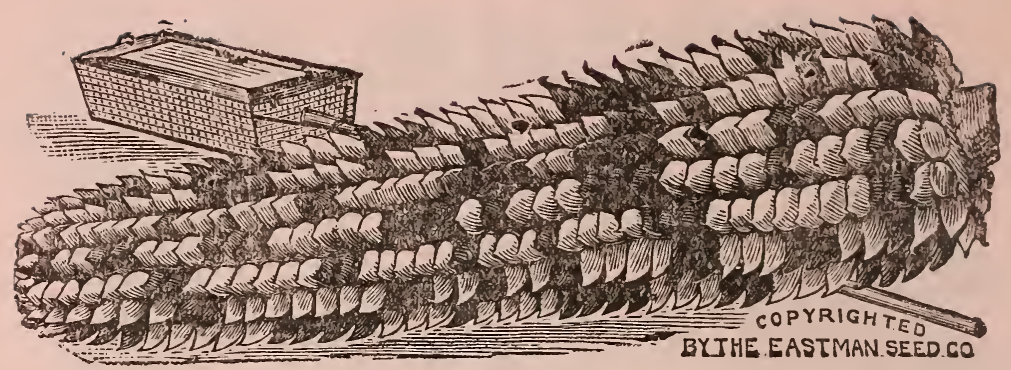

This curiously marked pop corn has proved one of the most taking novelties we ever put out. It is of the "rice" or "squirrel tooth" type, and the colors, golden yellow and tat too black, are in such marked contrast as everywhere to attract attention. Its fine afptat. ance, superior quality for popping, earliness and large yield, admirably fit it for a market variety as has been demonstrated. It is just the thing to take the premiums at the fairs in the fall. Our artist has endeavored to show its peculiar appearance as far as possible in black and white on a reduced scale.

Per quart $50 \mathrm{cts}$. (40 cts. by express;) pint $30 \mathrm{cts}$.; pkt. $5 \mathrm{cts}$.

\section{Farmer's Friend Potato.}

This variety was originally introduced by us as the "Nameless," and received its present name by vote of our customers. The

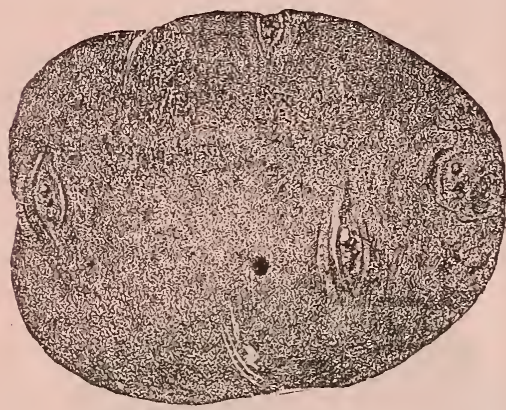

ten points of excellence claimed for it were (I) extreme earliness, (2) vigor of growth, (3) ability to withstand disease, (4) productiveness, (5) uniformity of size and small proportion of undersize, (6) fine shapenearly globular, (7) beauty of color-pure white with little splashes of red, especially about the eyes, (8) superior table quality either baked or boiled, (9) long-keeping characteristics, and ( 10 ) the best combination of the above points, making it an A r all-round potato.

It is sufficient to say that every claim was substantiated by the experience of our customers. From a single tuber one customer reports ten meals of fine potatoes for a family of three and a peck for seed. Another with ordinary culture raised I $3-4$ bushels from one pound of seed, with hardly a single small potato in the lot, and so on. On our own grounds they out-yielded the Green Mountain planted alongside and receiving the same culture, and while the latter rusted and rotted badly (neither were sprayed) this variety was nearly exempt.

Mr. Willis G. Jones of Connecticut, at whose suggestion Farmer's Friend was given a place among the names from which the final selection was made, writes:

Your Nameless Potato is all you claim tor it. I planted eleven kinds in one row. Nine of them rotted badis. Fours and one other did not rot at all. What the farmers want now is a round white or netted potato to take the place of the red Stray Beauty. Round Potatoes take the place of long ones in my market. The "Nameless" fills the place that is why I named it FARuER'S FrIEND.

By Express: Per bu., \$3.50; Peck, $\$ 1.00$ By Mail, postpaid: Per 1b., 25 c.; tuber, IO c.

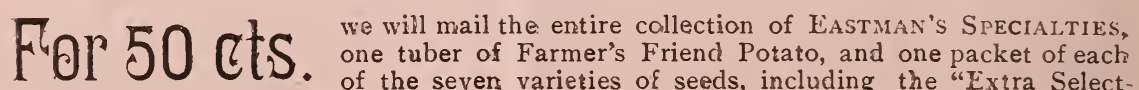
ed" strains of Tomato and Siveet Corn.

\section{All Seeds Pestpaid at prices herein namet, except wherec prices

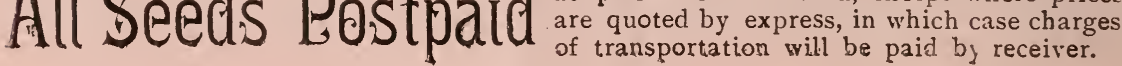




\section{PINE TREE STATE SEED COMPANY}

\section{FRIENDS AND PATRONS:}

This little book we place in your hands, hoping in so doing that you will be induced to place your order for Garden, Field and Flower Seeds with us.

It is not for a moment presumed we grow all our own seeds or that ours is the only good. seed in the market, but it is believed to be as good as the best; as pure, as fresh, of as high a grade, and as true to name as any.

There is no economy in buying cheap, inferior seed. We have carefully revised prices for our new Catalogue, and believe the figures will compare favorably with those of other dealers when quality is taken into aecount.

We do not put out anything but what we would be willing to plant ourselves.

We are now ready to again serve you with the largest and choicest stocks of seeds we have ever had. Should you favor us with an order large' or small, the same will be greatly appreciated and receive our prompt attention.

\section{To Our Old We hope we may have another order from you this season. We appre- Customers ciated your order last year and tried our best to please you. The old cus- tomers are the backbone of the business, but of course, we are always glad to get an order from a new one. We will look for another order from you and we want you to speak a good word for us to rour neighbors if you get a chance.}

\section{Why not get your Seeds Free?}

Your neighbors and friends will all have to have some seeds, and we can offer them a better deal than they can get anywhere else. Big packages, good, honest seeds and fair dealing. We have a number of customers who make a good thing taking orders for our seeds among their neighbors.

Try and get up a club, we will send you some extra catalogues and order blanks free. It will not cost you a cent to try anyway. If you don't get any orders no one is out anything but us and we will take a chance on it.

We will wrap each order separately and properly label them and will include lots of free packets.

When the seeds arrive, if everything is not just as we told you, you can have your money back. Ask the Bath National Bank of this city if we will stick to what we say. Write today for our terms. We will pay you a liberal cash commission to act as our agent.

\section{Seeds Cor Gardens for children are being established in many cities and} School Gardens towns as a part of the school curriculum. Children acquire more general knowledge of value in doing things than they could get from book study alone. To allow a child to grow up without planting a seed or rearing a plant is a crime against civilized society.

We hope in a few years to see an hour's garden work several times a week given to every child in the primary grades in all schools. We will be glad to correspond with teachers or others who desire to purchase seeds for this purpose. We will make special low rates on all kinds of seeds that are to be used for this purpose.

\section{To Members of the Grange \\ You can save money by getting up a Seed Club in your Grange and sending the order to us. Write for full information about the ad-} vantages secured on Grange orders.

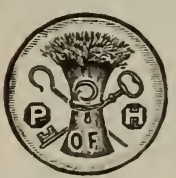

A beautiful Grange emblem pin free if your order amounts to a dollar or over. Be sure and state the name of your grange and if wanted for a lady or gentleman. These beautiful gold pins are in the shape of a shield and guaranteed to wear for years.

\section{PINE TREE STATE SEED CO.}

Order.-Early. Terms.-Our terms are cash. Renittances.-May be made by check, express or postoffice order or money in registered letter; small amounts in stamps. Packing.-We make no charge of boxes, bags or packing, or delivery to depot or express office. Seeds Postpaid by Mail. - We pay the postage on seeds by the packet, ounce and quarter pound. Add at the rate of ten cents per quart on corn and fifteen cents per quart on beans and peas. Address. - In ordering be particular to sign your name, postoffice, R. F. D. route, county and state, plainly. Small Orders. - If you only want a single packet, do not hesitate to send for it. Free Seeds. - With every order we shall include freeof charge, a liberal amount of Trial Packets. Seed Packets.-Oür Vegetable and flower Seeds are put up in neat packets, large and well filled. Agents.-We want an agent in every town. Write for terms.

25 cents WORTH OF SEEDS EXTRA WILL BE ALLOWED ON EACH 25 cents ONE DOLLAR SENT FOR SEEDS IN PACKETS AND OUNCES You will find an order sheet and return envelope in this book. Why not use it today. 


\section{Kind Words From Our Friends}

They are proofs of merit, such testimonials cannot be bought.

Lewiston, Maine, Nov., $1 \subseteq 07$.

"I received the bulbs I ordered and many more for which I thank you very much. You were more than generous with extras."

MRS. E. C. WELLMAN.

From the Maine Farmer: "The Pine Tree State Seed Company at Bath are importers and growers of pure and genuine flower and garderi seeds. Their seeds are fresh, true to name and of the finest quality, such as will produce nothing but the best. This company is to be warmly commended for their efforts to introduce Maine grown seeds."

A testimonial we are proud of, from the wife of the Past Master of the National Grange: South Bend, Ind.

"Having received a generous supply of seeds from you last spring, I am anxiously waiting for your catalogue to again send in my order. I cannot say enough in praise of the excellent quality of your seeds. They were perfect; not a seed failed to appear."

Very sincerely,

MRS. AARON JONES.

Good Will Farm, Hinckley, Maine.

April 3, 1908.

"Seeds arrived, safely and promptly and we were greatly pleased with them. You may feel sure of a larger order next year.

CHAS. F. NUTTER,

Asst. to Rev. G. W. Hinckley.

Berwick, Me., April 13, 1908.

"Your seeds came wonderfully and are the best seeds we have had. We can not praise your seeds nigh enough."

\section{MRS. LOVINA D. MURRAY.}

Randolph, Vt., May 1, 1908.

"The seeds came all right. We never had so many in a package before. They are bright looking seed, shall surely recommend them when ever we have an opportunity."

\section{GEO. C. FLINT.}

A pleasing testimonial from the wife of the Master of the Maine State Grange:

Alta, Maine, May 18, 1908.

"Accept my sincere thanks for your kindness in sending me so many extra packets. My Sweet Peas last seascn were the most beautiful I have ever had and all other seeds received from you gave perfect satisfaction. I enclose an order for vegetable seeds."

MRS. S. C. STETSON.
Perry, Maine.

"Received the seeds previously ordered and are much pleased with the size of the packages, and best of all we know that the seeds will all grow, as we have used your seeds before with the best results."

\section{LOUISE C. WASHBURN.}

Mr. E. H. Libby, Secretary of the Maine State Grange, writes as follows:

"The flower seeds received from you last spring were very fine and my wife was very much pleased with them. No one makes a mistake in buying your seeds."

\section{Lowell, Mass., March 2, 19 i) 5 .}

"While visiting in Maine last summer I had several bouquets brought to me, and the flowers were so beautiful and different from any I had ever seen, I had to ask where the seeds were bought, and your address was given me. If you have a catalogue please send me a copy."

MRS. C. C. BERRY.

Middlesex, Vt., May 3, 1908 .

"Received the seeds all right and an very" much obliged for the very generous amount of complimentary packages."

\section{J. A. CHAPIN.}

Riggsville, Me., Dec. 16, 1908.

"The vegetable seeds I bought of you last spring were the very best I have been able to buy since. I came to Maine, over five years ago. The Buckwheat, Barley and Hungarian grew all right. Will do my best to get others to buy your seed."

\section{W. F. NUTTER.}

Daybreak Farm, Readfield, Maine.

"I wish to say that our flower garden the past season was a constant source of delight. All seed germinated well and developed into healthy plants. The Sweet Peas and Asters were particularly fine, was awarded first premium on my Asters at Kennebec County Fair."

\section{ANNIE A. NICKERSON.}

Col. H. S. Foster of No. Cala:s, Vt., writes: "The seeds received from your house were $\mathbf{O}$. K. You will get an order from me soon and a good sized one."

Lisbon Falls, Maine, Dec. 10, 1909.

"Received my Grange pin it is a beauty. The seeds we received from you were all extra good and true to name."

\section{EVA M. CARVILLE,}

Secretary Pine Tree Grange.

Mere Point, Maine, Sept. 10, 1909.

"All the seeds received from you were excellent and paid for themselves many times over." EDITH SKOLFIELD SMITH. 
"Inglenook," Monmouth, Maine, Sept. 11, 1909 Pine Tree State seed Co., Bath,

"Simple justice prompts a recognition of the superior quality and germinating power of the garden and flower seeds ordered of you last spring. I never saw a richer assortment of Sweet Peas or greater wealth of bloom. I think them superior to any furnished by you the past ten years. I must attribute the earliness and abundance of garden crops to the same critical selection of seed and testify my appreciation of the same. Especially would I mention "Sutton's Excelsior" and "Admiral Dewey" Peas. Commenced using the last of June and they held good until the last half of August. I consider "Sutton's Excelsior" the richest, sweetest and best all round pea I ever grew, about one week later than the earliest but growing vigorously and bearing abundantly. For a later, rank growing, heary bearing pea, of choice quality, give me the "Admiral Dewey." Shall want a larger supply early in 1910 .

Very truly,

\section{G. M. TWITCHELL}

\section{SAN JOSE SOALE VAOUUM SPRAYOIL} MADE ONLY BY

VACUUM OIL COMPANY, Rochester, New York Send for booklet telling you how to SAVE YOUR TREES.

Buston Othice, 49 Federal St. New York Othice, 29 Broadway

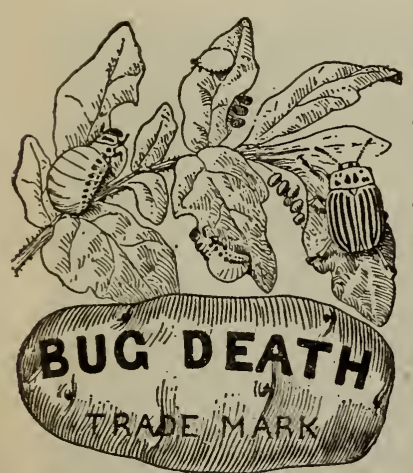

BU G. DEATH

The only insecticide in existence absoluitely harmless to use, which will kill the bugs and insects, protect the life of the leaves and plants. increase the yield, insure highest quality and promote the vigor of the plant.shub or vine. Bug Deatli is on sale at all first-class stores. If you do not find it, write us.

Danforth Chemical Co.

Manufacturers

Leominster, - Mass.

Pat. March 16 and Nov. 9, 1897 .

\section{Dickey Bug Death Duster}

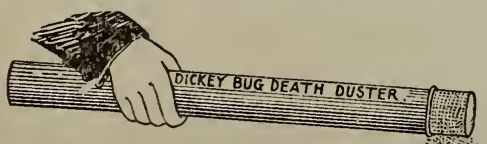

The most practical and cheapest implement for applying Bug Death and all dir powders. Price 25e.
Novelties and Specialties in Vegetable Seeds

CIRIMSON GLOBE BEFT. - This beet is remarkable for its smooth skin and fine shape, and it does not grow large and coarse. The flesh is very darli and quality fine, sweet and tender. Plit. 5c; oz. $15 \mathrm{c} ; 1-4.30 \mathrm{c}$.

BEFFSTEAK LETTUCE.-This grand new variety grows to an immense size, makes large loose heads of a rich and buttery flavor. The leaves are of a soft green tinged and flaked with red, never grows bitter. A fine summer variety. Plit. 10c; oz. 30c.

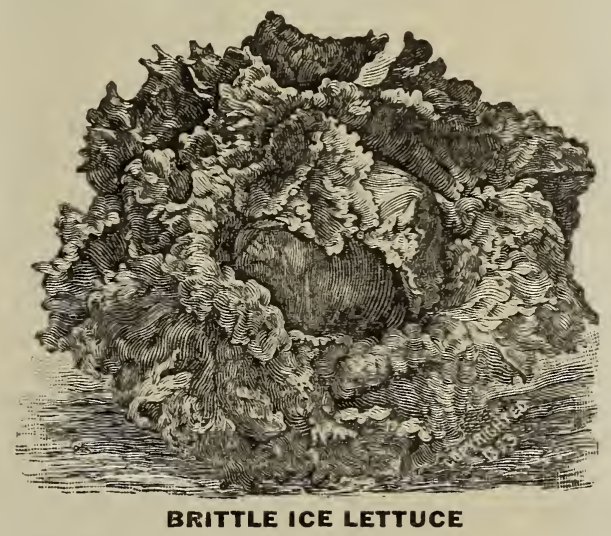

LETTUCE, BRITTLE ICE.-Very large, extremely crisp, hard-heading variety. The plants grow to a large size, sweet and mild in flavor. Pkt. $10 \mathrm{c}$; oz. $25 \mathrm{c}$.

LETTUCE, MAY KING.-A new early head lettuce, its growth is extremely rapid and its fine large heads are ready in advance of any other heading variety. Crisp and very brittle. Pkt. $10 \mathrm{c}$; oz. $25 \mathrm{c}$.

ALI SMOOTH CUCUMBER.-A variety of the highest merit. The fruits are large, extra smooth and very regular in forn a rich dark green color, retaining its color until fully ripe, the smoothest cucumber grown. Pkt. $10 \mathrm{c}$; oz. 20.

SENATOR PEA.-A grand new second early pea. The vines grow to about 2 feet high filled with enormous pods. You will be de. lighted with the quality and quantity. Pkt. 1 oc; pt. $20 \mathrm{c}$; qt. $35 \mathrm{c}$.

SC'TTONS EXCELSIOR PEA.-A new early dwarf English variety. Pods very large and weil filled with delicious flavored peas. Grows about 18 inches high. Plit. 10c; pt. $15 \mathrm{c}$; qt. $30 \mathrm{c}$; pk. $\$ 2.25$.

PRINCE EDIVARD PEA.-A brand new large wrinkled sort, produces the largest and best filled pods of any pea in existence. A very heavy cropper, pods of immense size, a rich dark green. Grows 3 to 4 feet high. Plit. $15 \mathrm{c}$; pt. $20 \mathrm{c}$; qt. $35 \mathrm{c}$; ple. $\$ 2.50$. 
VOLGA CABBAGE.-A new variety from Russia. We highly recommend it as a mid-sum. mer to fall sort. It grows very uniform, heads nearly round, and of equal size and is one of the most remarkable heading sorts we erer saw. Pkt. $10 \mathrm{c}$; oz. $30 \mathrm{c}$.

THE NEW DAVIS PERFECT CLCUMBER.This new variety beats all others in points of heauty, quality and productiveness, a beautiful dark green color, handsome shape and enormously productive. This variety enables one who has not glass to produce the same high priced cucumbers as those grown in a greenhouse. Pkt. $10 \mathrm{c}$; oz. $20 \mathrm{c}$; $1-41 \mathrm{~b} .50 \mathrm{c}$.

MUSK MELON GOLDEN GEM.-A new round variety, flesh deep rich orange and of the most exquisite flavor. Pkt. $10 \mathrm{c}$; oz. $20 \mathrm{c}$.

PEEP-O'DAY SWEET CORN.-Ten days Earlier than any other sort and the sweetest of all Extra Early Corn. The stalks 3 1-2 to 4 1-2 feet high and bear from two to five ears, will stand very close planting. Pkt. $10 \mathrm{c}$; pt. $15 \mathrm{c}$; qt. $25 \mathrm{c}$.

GOLDEN BANTAM SWEET CORN.-One of the best extreme early varieties. Dwarf and sturdy in habit, growing about four feet high and bearing two and three good ears to each stalk. The ears five or six inches in length having eight rows of broad yellow grains of a delicious flavor. Pkt. 10c; pt. $15 \mathrm{c}$; qt. $30 \mathrm{c}$; selected ears $10 \mathrm{c}$ each.

DELICIOUS SQUASH.-A superior fall and winter variety that for thickness of flesh and richness of flavor is unsurpassed. Color a handsome green, weighing from 5 to 10 pounds. Pkt. $5 \mathrm{c}$; oz. $15 \mathrm{c}$; $1-4$ lb. $35 \mathrm{c}$.

ADMIRAL DEWEY TOMATO (new).-One of the finest in every respect, early, smooth and uniformly handsome, ripens clear up to the stem, superior to all other varieties for main crop for canning or shipping, of large size and bright scarlet color. Pkt. $10 \mathrm{c}$; oz. $35 \mathrm{c}$.

TOMATO CHALKS EARLY JEWEL.-The largest of the extra early bright red tomatoes. The plants are immensely productive, sweet flavored and very early. Pkt. $10 \mathrm{c}$; oz. $35 \mathrm{c}$.

EARLY JUNE PINK TOMATO.-This new variety is a beautiful deep pink in color, very early and of fine flavor, sweet and mild. The fruits are set in large clusters. Pkt. $10 \mathrm{c}$.

EARLIANA TOMATO. -The earliest smooth, bright red tomato of good size and flavor now in cultivation. The plants are hardy, well set with fruit, nearly all of which ripen extremely early in the season. The flesh, a deep red. Pkt. $10 \mathrm{c}$; oz. $30 \mathrm{c}$.

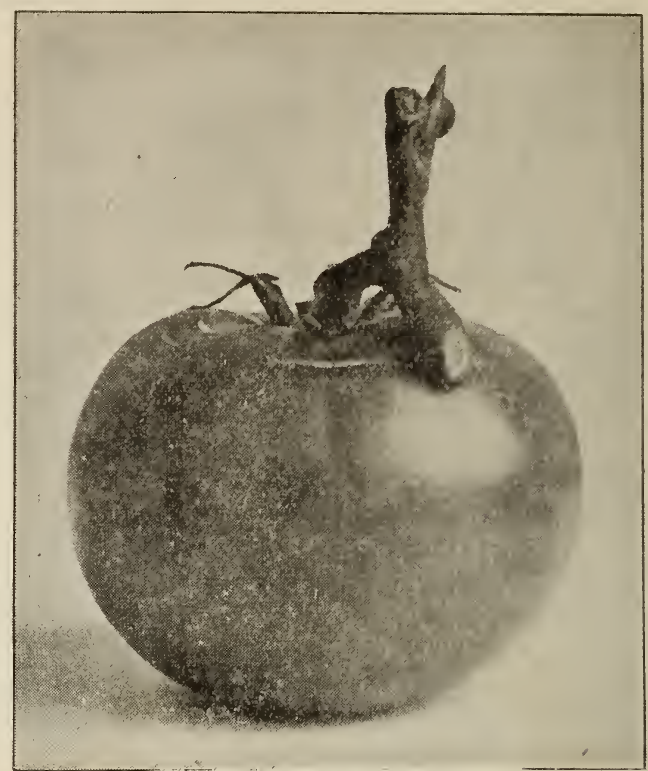

ADMIRAL DEWEY TOMATO

IAXTONIAN PEA.-In all respects the greatest advance yet made in Dwarf Early Peas. A vigorous grower. Eighteen inches high. The pods are very large averaging nine to ten in a pod. Very early. Pkt. 15c; 1-2 pt. $35 \mathrm{c}$; pt. $60 \mathrm{c}$.

WATER MELON YANKEE.-Best for New England. This new melon is a fine variety for the family and market, very early and proiific. The bright red flesh is cool, crisp and sweet. Will mature anywhere in Yankee land. Pkt. $10 \mathrm{c}$; oz. $25 \mathrm{c}$.

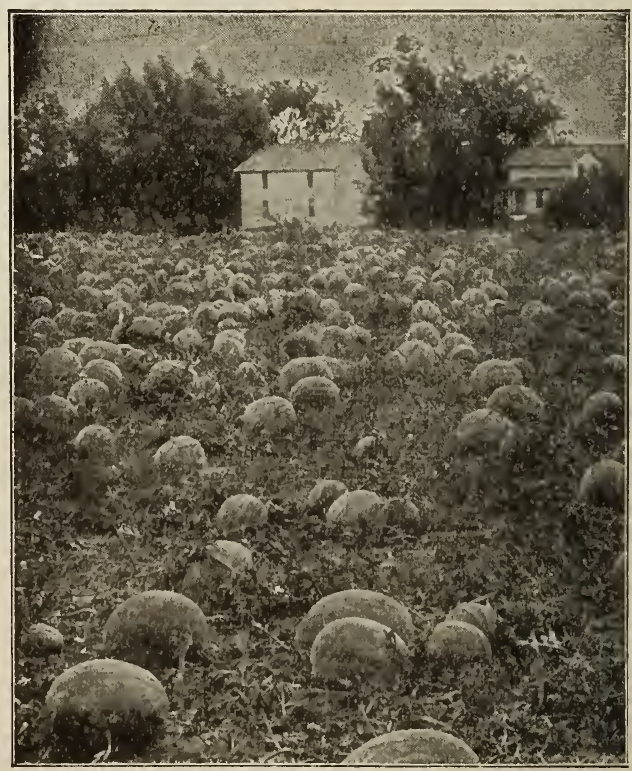

WATER MELON YANKEE 
CORX GOLDEX NIGGET.-Sweetest on Earth. The ears of this new Golden Sweet Corn are larger and more prolific than Golden Bantam, tender and unusually sweet. Ready for market only a few days behind the earliest. Pkt. $15 \mathrm{c}$; pt. $20 \mathrm{c}$; qt. $40 \mathrm{c}$.

\section{New Sweet Peas}

COUNTHSS OF SIPNCER.-Large way petals, soft rose-pink in color, free flowering. The large, handsome flowers are produced or long stems. Plit. $10 \mathrm{c} ;$ oz. $25 \mathrm{c}$.

WHITF SPENCWR.-Pure white of large size beautifully crinkled and fluted. The flowers are borne three and four on a stem and corered with blooms throughout the season. Plit. $10 \mathrm{c}$; oz. $25 \mathrm{c}$.

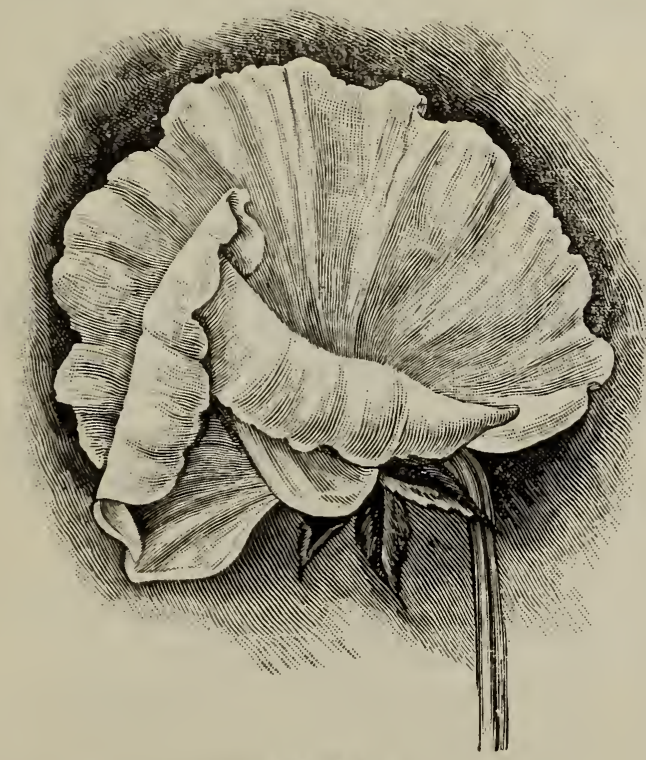

WHITE SPENCER

PRIMROSE SI'FNCER.-Like the above only the color is a primrose or creamy yellow. Pkt. $10 \mathrm{c} ;$ oz. $25 \mathrm{c}$.

FLOREYCE MORSE SPENCER.-A light pink edged variety very beautiful, borne upon strong stiff stems, four flowers to each stem. Plit. $10 \mathrm{c} ;$ oz. 2 ə̃.

FRANK DOLBY.-A lovely light lavender, has a bold wavy standard with wile spreading wings, beautifully fluted. Pkt. $10 \mathrm{c} ;$ oz. $25 \mathrm{c}$.

E. J. CASTIL. - A rich Carmine Rose with salmon shading. Standard crinkled and waved. Plit. $10 \mathrm{c} ; 0 \mathrm{z} .25 \mathrm{c}$.

BLACK BIII).-Very deep purplish maroon almost black, wings darkest claret, hooded form. Pkt. $10 \mathrm{c} ;$ oz. $25 \mathrm{c}$.

DAIXI - - A beautiful large flower, upon first opening appears to be white but quickly changes to white with a pink ed ze. Pkt. $10 \mathrm{c} ;$ oz. $20 \mathrm{c}$.
QULEN OF SPAIN.-A delicate peach-blossom pink tinged with apricot. Pkt. 10c; oz. $25 \mathrm{c}$.

BOLTON'S PINK.-Large bold flower, very showy, of a soft salmon-orange pink. Pkt. $10 \mathrm{c} ; 0 \mathrm{z} .15 \mathrm{c}$.

GI.ADYS UNWIN. - A large bold flower of the New Orchid flower type, a lovely pink in cosor. Pkt. $10 \mathrm{c}$; oz. $20 \mathrm{c}$.

SC.IRLET GEM.-Dazzling scarlet, bright and clear and wonderfully free flowering. Pkt. $10 \mathrm{c}$; oz. $15 \mathrm{c}$.

HELEN PIERCE.-A new gloximia-flowered type, bright blue mottled on white, of good size. Pkt. 10c; oz. $15 \mathrm{c}$.

FLORA NORTON.-A beautiful rich lavender. The flowers are large and fine form. Pkt. $10 \mathrm{c} ;$ oz. $20 \mathrm{c}$.

VIOLET IIING.-A deep glowing violet purple. A strong grower. Pkt. $10 \mathrm{c}$; oz. $20 \mathrm{c}$.

MIRS. AARON JONES.-This beautiful new Sweet Pea was named in honor of the wife of the Master of the National Grange. The color is a soft but brilliant pink. A fine large flower and of strong, vigorous growth. Pkt. 10c; oz. $15 \mathrm{c}$.

MPS. HIGGINSON.-A delicate lavender. Best of all lavender sorts. Pkt. $5 \mathrm{c}$; oz. $15 \mathrm{c}$.

IING EDWARD VII.-Bright crimson of enormous size and borne upon long stems. Pkt. $5 \mathrm{c} ;$ oz. $15 \mathrm{c}$.

ROYAL KNIGHT.-A deep glossy maroon. The best of all the dark maroons. Pkt. 10c; oz. - o

WILD ROSE.-Flowers almost uniformly three on a stem, of large size, a deep rose pink. Pkt. $10 \mathrm{c}$; oz. $15 \mathrm{c}$.

MISS WILMOTT.-A new English variety. Of the richest orange pink, delicately shaded rose. These enormous flowers are borne erect on stiff, long stems. Pkt. 5c; oz. 10c.

THE HON MRS. E. IENYON.-A beautiful, primrose color. Pkt. 5c; oz. $10 \mathrm{c}$.

DOROTHY EOKFORD.-A splendid, new early white Sweet Pea. The flowers are of a fine paper white, of good size. Pkt. 5c; oz. $15 \mathrm{c}$. Ten packets of any of the above new varieties for 50c. postpaid.

\section{New Tall Nasturtiums}

ALL NASTURTIUM, 'TWLIGHT.-The flowers are extra large in size and of the full, expanded form. They are most distinct and pleasing in color, having a faint salmon or buff tint heavily overlaid or suffused with a deeper rosy salmon. Plkt. $10 \mathrm{c}$.

TALI, NASTERTIUM, MOONLIGHT.-This is a companion variety to the preceding, with flowers fully equal in size, but of an exquisite pale straw yellow. Pkt. 10c; oz. $15 \mathrm{c}$. 
'TALL NASTUR'TIUM, SUNLIGHT.-This grand variety bears flowers of largest size, most beautifully colored-clear, rich golden yellow, and are produced so profusely as to almost conceal the large dark green foliage. Pkt. $10 \mathrm{c} ;$ oz. $15 \mathrm{c}$.

'TALL NASTUR'TIUM, MIDNIGHT.-The foliage is a deep, dark green and bears an abundance of bloom of wonderful rich coloring, the darkest of all nasturtiums. The flowers are deep, brownish red and are borne profusely. Pkt. 10c; oz. $15 \mathrm{c}$.

TALL NASTURTIUM CAPRICE.-The flowers are of extra large size in a wonderful variety of colors. Pkt. $10 \mathrm{c}$; oz. $20 \mathrm{c}$.

TALL NASTURTIUM, PRESIDEN'T McKINLEY. -Both flowers and foliage are of a rich, dark coloring, the flowers being a deep, rich velvety crimson, profuse bloomer. Pkt. $10 \mathrm{c} ;$ oz. $20 \mathrm{c}$.

TALL NASTURTIUI VARIEGATED LEAVED. -A new race of Nasturtiums, every leaf is variagated, with yellow, white, and green beautifully blotched and striped. The flowers of many bright colors in charming contrast to the handsomely varigated foliage. Plat. $10 \mathrm{c}$; oz. $35 \mathrm{c}$.

TALL NASTURTIUM IVY LEAVED.-The leaves are of a rich green veined with white resembling the foliage of the English Ivy. The flowers are of many colors and star-like in appearance. Pkts. $10 \mathrm{c}$.

Five packets of any of the above for $30 \mathrm{c}$.

RAINBOW MIXTURE, TALI NASTUR'TIUM. -The most showy and varied in color of all Running Nasturtiums, the mixture contains over thirty of the choicest named varieties, exceedingly fragrant and fower freely until severe frost. Plit. $10 \mathrm{c}$; oz. $15 \mathrm{c} ; 1-4$ lb. $40 \mathrm{c}$.

\section{Flower Seed Novelties}

POPPY ADMIRAL.-A beautiful single poppy of glistening pure white, with a broad band of scarlet around the top. Pk.t. $10 \mathrm{c}$.

COREOPSIS SUNSHINE MITLRE.-This mixture includes all the choicest varieties of the Coreopsis family and named in honor of the Sunshine Society, who have adopted this bright and beautiful flower for their society flower. Pkt. $10 \mathrm{c}$.

PANSY MASTERPICCE (New Giant Curled or Rufled Pansy).-A remarliable new type amongst all the existing Pansies. The chief difference from other Pansies consist in the very original form of the flowers, the border of every petal being conspicuously undulated and curled. Pht. $20 \mathrm{c}$.

ASTER FARLY SNOWDRIFT.-Very early, each plant produces twelve to twenty long upright stems crowned with large feathery flowers. Very gracefully. Plit. $15 \mathrm{c}$.

ASTER LAVENDER GEM.-Large double flowers of exquisite lavender shade of the Ostrich feathered type. The flowers are borne in profusion on long stems. Pkt. $15 \mathrm{c}$. One packet each of the above asters for $25 \mathrm{c}$.

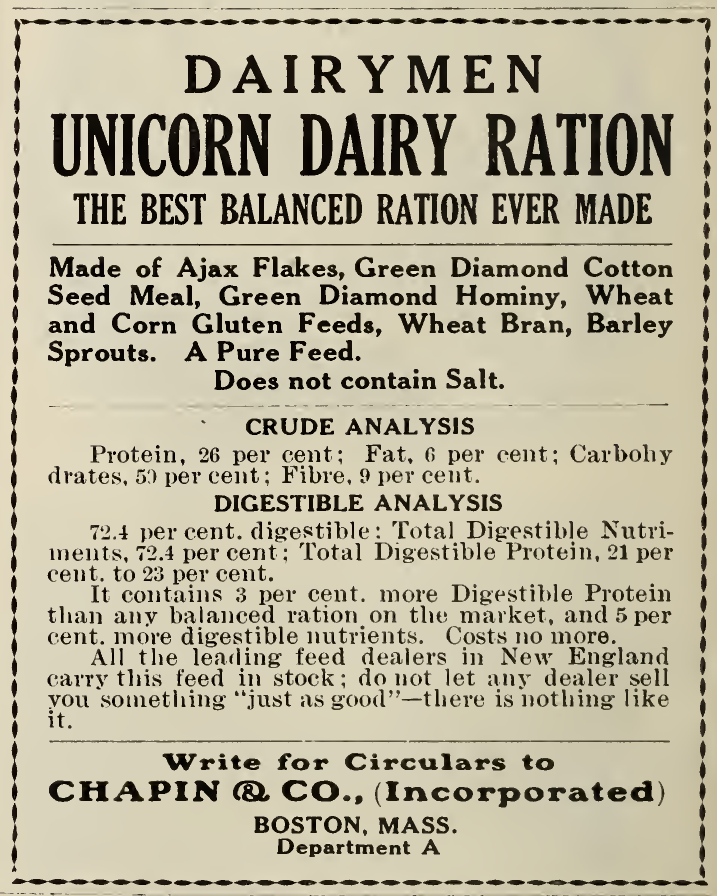

\section{“REVERO'”}

Non-Kinking Hose

Braided Fabric Seamless Throughout Moulded Construction

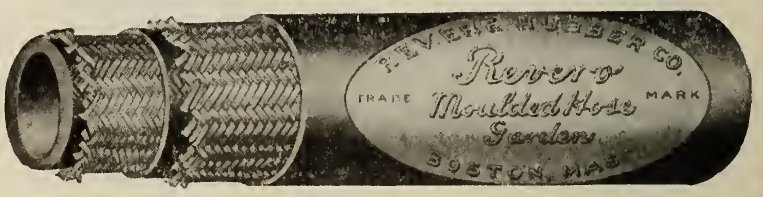

The Modern Garden Hose for Gardens, Lawns, Greenhouses, Stahles. Ftc. Made in continuous lengths up to 500 feet, also in fifty foot lengths. Oriler any length.

REVERE RUBBER COMPANY 


\section{Reliable Vegetable Seeds}

\section{Asparagus}

P.IMETTO.-Bright green color; very desirable. Plit. 5c; oz. $10 \mathrm{c} ; 1-4$ lb. $30 \mathrm{c}$.

\section{Beans (Dwarf or Bush)}

If by mail, postage must be added at the rate of 15c. per quart.

GOLDEN EYED WAX.-Early, hardy and productive. No finer wax bean known. Pkt. $10 \mathrm{c}$; pt. $15 \bar{c}$; qt. $30 \mathrm{c}$.

RUST PROOF WAX.-Pods long, nearly straight, broad, flat, golden yellow, stringless and brittle. Plkt. $10 \mathrm{c}$; pt. $15 \mathrm{c}$; qt. $30 \mathrm{c}$.

MARBLEHEAD EARLY HORTICULTURAL. One of the earliest, large rich-colored pods, excellent either for shelling or stringing. Pkt. 10c: pt. $15 \mathrm{c}$; qt. $30 \mathrm{c}$.

DWARF HORTICULTCRAL.-Resembles Pole Horticultural, a fine snap or shell bean. Pkt. 10c; pt. $15 \mathrm{c}$; qt. $25 \mathrm{c}$; peck $\$ 1.50$.

BUTPEES BUSH LIMA.-This bean grows from fifteen to eighteen inches high, in a compact bush form, and produces heavy crops. Two weeks earlier than the common Lima. Pkt. 10c; qt. 30c.

REI KIDNEY.-Fine for baking. Pt. 15c; qt. $25 \mathrm{c}$.

LOW'S CHAMPION.-Early, hardy and enormously productive-large podded, stringless and very tender. Pkt. $10 \mathrm{c}$; pt. $15 \mathrm{c}$; qt. $25 \mathrm{c}$.

BLRPEES NEW STRINGLESS GREEN POD.For either the market or home garden, no other green-podded bean is so satisfactory. The pods are a rich green, round and straight, five inches long, solid, meaty and broad, always tender and brittle, and of finest flavor and entirely stringless. Pkt. $10 \mathrm{c}$; pt. $15 \mathrm{c}$; qt. $25 \mathrm{c}$.

DETROIT WAX.-Early and productive. $\mathrm{Pt}$. $15 \mathrm{c} ;$ qt. $30 \mathrm{c}$.

\section{Beans (Pole or Running)}

POLE HORTICULTURAL.-Excellent as a string or shell bean. Pkt. 10c; pt. 15c; qt: $25 \mathrm{c}$.

RED CRANBERRY.-The good, old-fashioned variety, tender and excellent. Pkt. $10 \mathrm{c} ; \mathrm{pt}$. $15 \mathrm{c}$ : qt. $25 \mathrm{c}$.

MAMMOTH PODDED HORTICULTURAL.The vine is very vigorous, pods very large, bright carmine, slightly streaked, very handsome and exceedingly productive. Beans large, splashed and spotted with red, either green or dry. Pkt. 10c; pt. 15c; qt. $30 \mathrm{c} ; 2$ qts. $50 \mathrm{c}$.
FSSEX CRANBERRY OR BOBOLINK.-Very hardy, early and productive. A fine snap bean. Pkt. $10 \mathrm{c}$; pt. $15 \mathrm{c}$; qt. $30 \mathrm{c}$.

LAZY WIFE'S. - Abundantly productive, and of excellent flavor, with long green, fleshy and stringless pods. Fine for shelling or baking when dry. Pkt. $10 \mathrm{c}$; pt. $15 \mathrm{c}$; qt. $30 \mathrm{c}$

FXTRA EARLY IIMA.-Earlier than the common sorts. Pkt. 10c; qt. $30 \mathrm{c}$.

EARLY GOLDEN CLUSTER WAX.-The pods of this variety are enormously large and long and borne in clusters. Plit. $10 \mathrm{c}$; pt. $20 \mathrm{c} ;$ qt. $35 \mathrm{c}$.

SCARLET RUNNER.-Very ornamental, free climbers, bright scarlet flowers. Pkt. 10c; pt. $20 \mathrm{c} ;$ qt. $35 \mathrm{c}$.

WHITE RUNNER.-Very pretty planted with the scarlet runner. Pkt. $10 \mathrm{c} ;$ pt. $20 \mathrm{c} ; \mathrm{qt}$. $35 \mathrm{c}$.

KENTUCKY WONDER.-Very early and very productive. The pods though large cook tender and delicious. Pkt. 10c; pt. 15̄c; qt. $30 \mathrm{c}$.

WHITE DUTCH CASE-KNIFE.-This variety has large flat pods, one of the earliest and very productive. Pkt. $10 \mathrm{c} ; \mathrm{pt} .15 \mathrm{c}$; qt. $25 \mathrm{c}$.

\section{Beets}

CRIMSON GLOBE (new).- See novelties.

EARLY BLOOD TURNIP.-A standard sort, early, round and smooth. Plet. 5c; oz. $10 \mathrm{c}$; 1-4 lb. $20 \mathrm{c}$; lb. $50 \mathrm{c}$.

ARLING'TON FAVORITE.-New and improved variety of medium size, dark rich color, of excellent quality. Pkt. 5c; oz. 10c; 1-4 $1 \mathrm{~b}$. $20 \mathrm{c} ; 1 \mathrm{~b} .60 \mathrm{c}$.

ECLIPSE.-One of the best early sorts, fine grained crisp and tender. Pkt. 5c; oz. 10c; 1-4 lb. $20 \mathrm{c}$.

DIRIGO.-Very early for forcing, a market gardeners sort. Pkt. 5c; oz. 10c;1-4 lb. $25 \mathrm{c}$.

SIVISS CHARD.-Used as greens. Plit. 5c; oz. 10c.; 1-4 lb. $20 \mathrm{c}$.

DEWING'S IMPROVED TURNIP.-Of fine form and flavor, and good color, a desirable variety. Pkt. 5c; oz. $10 \mathrm{c} ; 1-4$ lb. $20 \mathrm{c} ; 1 \mathrm{~b}$. $50 \mathrm{c}$.

PETROIT DARK RED.-One of the very best sorts, either for market or home use. Tops small roots globular and very smooth skin dark red, flesh bright red. Very crisp, tender and sweet. Pkt. 5c; oz. $10 \mathrm{c} ; 1-4 \mathrm{lb}$. 2. $0 \mathrm{c} ; 1 \mathrm{~b} .65 \mathrm{c}$.

BASTIN'S EARLY BLOOD TURNIP.-Very early, of quick, large growth; fine turnip form and bright red color. Pkt. 5c; oz. $10 \mathrm{c} ; 1-4$ lb. $20 \mathrm{c}$. 


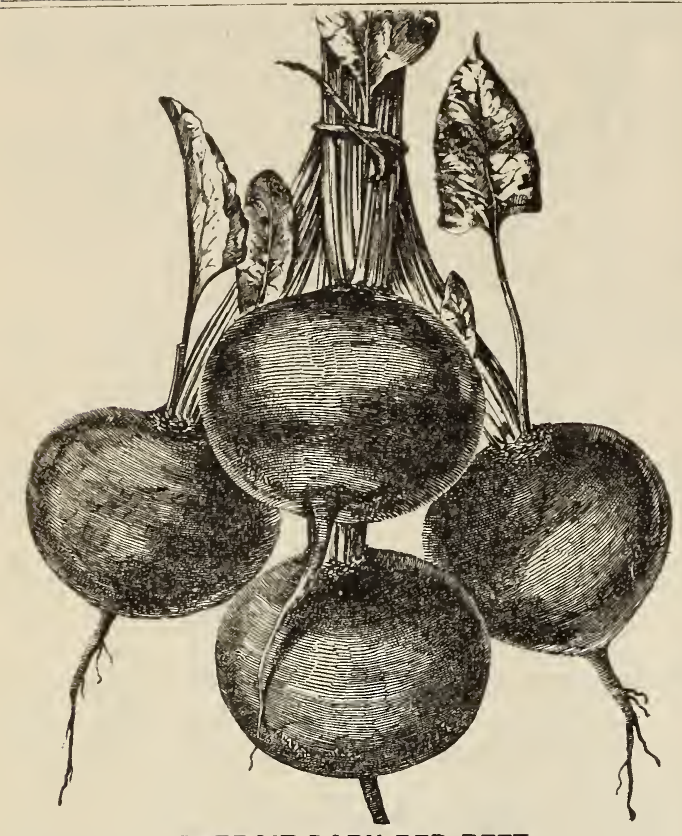

DETROIT DARK RED BEET

CROSB'S'S EGYP'TIAY.-For early use, either for market or family gardens, this variety easily takes the lead. Pkt. $5 \mathrm{c} ;$ oz. $10 \mathrm{c} ; 1-4$ lb. $20 \mathrm{c}$; 1b. $65 \mathrm{c}$.

EDMAND'S TLRXIP.-The flesh is deep blood red in color and exceedingly sweet and tender in quality. Pkt. 5c; oz. $10 \mathrm{c} ; 1-4 \mathrm{lb}$. $20 \mathrm{c} ; 1 \mathrm{~b} .60 \mathrm{c}$.

\section{Mangel Wurzel}

CARTER'S ORANGE GLOBE.-Best variety of yellow globe.

LANE'S IMPERIAI SUGAR.-Long white va. riety, excellent for feeding stock.

MAMMOTH LONG RED.-Producing roots oi mammoth size. This is the best long red.

GATE POST.-Heavy cropper, small top. Price each, per oz. 5c; 1-4 lb. 15c; lb. 35c.

\section{Brussel Sprouts}

IMPROVED EXTRA.-Closely covered with large, compact sprouts. The very best sort. Pkt. $10 \mathrm{c} ;$ oz. $30 \mathrm{c}$.

\section{Cabbage}

EARLY JERSEY WAKEFIEID.-Very early, sure heading, pyramidal shape. Pkt. 5c; oz. $20 \mathrm{c} ; 1-4$ lb. $65 \mathrm{c} ; 1 \mathrm{~b} . \$ 2.00$.

HENDERSON'S EARLY SCMMER.-Earliest of all the large cabbages, solid and compact. Pkt. 5c; oz. $20 \mathrm{c} ; 1-4$ lb. 50c; 1b. $\$ 2.00$.

DANISH BALI, HFAD CABBAGE.-The hardest heading cabbage in existence, and of excellent quality, white, crisp and tender. The heads are round, fine-grained and a good keeper. Pkt. $10 \mathrm{c} ;$ oz. $30 \mathrm{c} ; 1-4$ lb. 7 5̃c.
EARLY WINNIGSTADT.-Heads large, coneshaped, solid, one of the best for all soils. Pkt. 5c; oz. 20c; 1-4 1b. 50c; 1b. $\$ 2.00$.

HENDERSON'S SUCCESSION.-One of the finest cabbages in existence, whether for medium, main crop or winter use. Pkt. ǰc; oz. $30 \mathrm{c} ; 1-4$ lb. $60 \mathrm{c} ;$ lb. $\$ 2.00$.

PREMIUM FLAT DUTCH.-Excellent winter variety. Pkt. $5 \mathrm{c} ;$ oz. $20 \mathrm{c} ; 1-4$ lb. $50 \mathrm{c} ; 1 \mathrm{~b}$. $\$ 2.00$.

BURPEE'S SUREHEAD.-Heads remarkably uniform, very hard and firm. A good keep-

er. Plkt. 5̃c; oz. 25c; 1-4 lb. $60 \mathrm{c}$; lb. $\$ 2.00$.

ALL SEASONS.-An early drumhead, sure headings, solid variety. Pkt. 5̌c; oz. $25 \mathrm{c}$; $1-4$ lb. $60 \mathrm{c}$.

FO'TTLER'S IMPROVED BRUNSWICK.-An excellent early drumhead variety, produces a firm and solid head. Plit. 5c; oz. 20c; 1-4 lb. $60 \mathrm{c} ; 1 \mathrm{~b} . \$ 2.00$.

MAMMOTH RED ROCK.-Best and deepest blood red. Pkt. 5̄c; oz. $25 \mathrm{c}$.

IVARREN STONE MASON.-A fine late variety. In reliability for heading no cabbage surpasses it; an excellent sort to carry through the winter. Plkt. 5c; oz. $30 \mathrm{c} ; 1-4$ 1b. $75 \mathrm{c}$; lb. $\$ 2.50$.

BURPEES SHORT STEM DRCMHEAD.-Uniform in heading and dwarf in growth, so a large number of heads can be raised on an acre. With good cultivation heads attain a weight of twenty to thirty pounds. Our seed is Maine grown, very fine: Pkt. 5̃c; oz. $25 \mathrm{c} ; 1-4$ lb. $80 \mathrm{c}$.

\section{FREE FROM WORMS FRUIT and VEGETABLES} SPRAY WITH

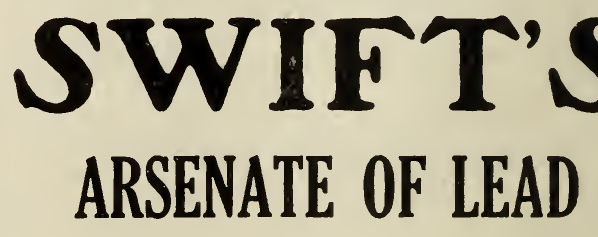

FOR

\author{
POTATO BUGS \\ CODLING MOTHS
}

and All Leaf Eating Insects MADE ONLY BY THE

MERRIMAC CHEMICAL C(.

33 Broad Street, Boston, Mass. WRITE FOR FREE BOOKLET 


\section{Carrots}

EARLY FRENCH FORCING.-Very early and small. Pkt. 5c; oz. $10 \mathrm{c} ; 1-4$ lb. $25 \mathrm{c}$.

OXHEART.-Very thick, enormous cropper. Pkt. 5c; oz. $10 \mathrm{c}$; $1-4$ lb. $25 \mathrm{c}$; lb. $75 \mathrm{c}$.

IMPROVED DANVERS.-Best main crop variety, fine quality, a great yielder. Pkt. 5c; oz. $10 \mathrm{c} ; 1-4$ lb. $25 \mathrm{c}$; 1b. $75 \mathrm{c}$.

LONG ORANGE IMPROVED.-Roots large and long, yields large crops. Pkt. 5c; oz. $10 \mathrm{c}$; $1-4$ lb. $20 \mathrm{c}$; $1 \mathrm{~b} .65 \mathrm{c}$.

CHANTENAY.-Early of a rich dark orange color, fine for bunching. Pkt. $5 \mathrm{c}$; oz. $10 \mathrm{c}$; $1-4$ lb. $30 \mathrm{c} ; \mathrm{lb} .80 \mathrm{c}$.

LARGE WHITE BELGIAN.-Very large, good keeper, fine for stock. Pkt. 5c! oz. $10 \mathrm{c}$; 1-4 lb. $20 \mathrm{c}$; lb. $60 \mathrm{c}$.

\section{Cauliflower}

IMPERIAL.-Very fine, early, large heading variety. Pkt. $15 \mathrm{c}$.

EARLY FAVORITE.-One of the best large growing, early kind, forming solid heads. Plit. $15 \mathrm{c}$.

HENDERSON'S EARLY SNOWBALL.-An extremely early dwarf variety, producing large white heads of the finest quality. Pkt. $20 \mathrm{c}$.

EARLY DWARF ERFURT.-Very early dwarf, compact heads tender and delicious. Pkt. $15 \mathrm{c}$.

SNOWSTORM.-New early dwarf variety with beautiful snowy heads. Very early. Pkt. $20 \mathrm{c}$.

LARGE DANISH.-Large, white, solid heads keeps well in dry weather. Pkt. 15c.

\section{Cress, or Pepper Grass}

Extensively used as a small salad. Pkt. 5c; oz. $10 \mathrm{c}$.

\section{Celery}

WHITE PLUME.-Crisp, solid and of a sweet, nutty flavor; needs very little earthing up. Pkt. $5 \mathrm{c}$; oz. $20 \mathrm{c}$.

PINK PLUME.-Similar to White Plume. The inner leaves and stalks are tinged with pink. Pkt. 5c; oz. $20 \mathrm{c}$.

NEW GOLDEN SELF-BLEACHING.-This is the best celery for early use, in color a beautiful golden yellow, very tender and of a fine nutty flavor. Pkt. $5 \mathrm{c}$; oz. $25 \mathrm{c}$.

BOSTON MARKET.-A favorite variety, peculiarly mild flavor; keeps well. Pkt. $5 \mathrm{c}$; oz. $20 \mathrm{c}$.

GIANT PASCAL.-An easy blanched variety, superior for late use. Pkt. $5 \mathrm{c}$; oz. $20 \mathrm{c}$.

\section{Sweet Corn}

Add 5c. per pint, 10c. quart, if ordered by mail. I'EEP-O'-DAY.-See novelty page.

GOLDEN NUGGET.-See novelty page.

PREMO SWEET CORN.-Very early and of a delicate sweet flavor. Pkt. 10c; pt.. 15c; qt. $30 \mathrm{c}$.

GOLDEN BANTAM.-See Novelty page.

WHITE COBB CORY.-The ears are fully as large and well filled as Cory, and just as early, having a clear white grain and white cob, making it one of the best extra early varieties. Pkt. $10 \mathrm{c}$; pt. $15 \mathrm{c}$; qt. $25 \mathrm{c}$.

EARLY CROSBY. - The very best early sweet corn, habit dwarf, ears set low, twelve to sixteen rowed and of rich flavor. Pkt. $10 \mathrm{c}$; pt. $15 \mathrm{c}$; qt. $25 \mathrm{c}$; selected ears $5 \mathrm{c}$; by mail $8 \mathrm{c}$.

POTTER'S EXCELSIOR.-One of the sweetestand best main crop varieties, a little later than Crosby. Pkt. $10 \mathrm{c}$; pt. $15 \mathrm{c}$; qt. $25 \mathrm{c}$.

BLACK MEXICAN.-Late. sweetest of all. Pkt. $10 \mathrm{c}$; pt. $15 \mathrm{c}$; qt. $25 \mathrm{c}$; selected ears $5 \mathrm{c}$; by mail $8 \mathrm{c}$.

COUNTRY GENTLEMAN.-The sweetest and most tender of all sweet corns. Kernels and cob pure white; cob small, kernels deep; ears average twelve inches in length. Pkt. $10 \mathrm{c}$; pt. $15 \mathrm{c}$; qt. $25 \mathrm{c}$.

STOWELL'S EVERGREEN.-A late standard variety, ears very large, keeps green till cold weather. Pkt. $10 \mathrm{c}$; pt. $15 \mathrm{c}$; qt. $25 \mathrm{c}$.

\section{Fodder and Field Corn}

SWEET FODDER CORN.-This variety excels all others for feeding to stock. Qt. 15c; pk. $65 \mathrm{c}$.

LEAMING.-An early, hardy, dented flint variety. It is tall and leafy with large ears: wili mature in New England. The best for ensilage. Qt. $15 \mathrm{c}$; pk. $50 \mathrm{c}$.

LONGFELLOW.-The best early yellow variety, having long ears, large kernels and small cob; yields immense crop. Safe to plant in New England. Qt. $20 \mathrm{c}$; pk. 60c.

EARLY YELLOW MAINE.-A fine yellow variety, long ears, matures early. Qt. $20 \mathrm{c}$; pk. $65 \mathrm{c}$; bu. $\$ 2.00$.

EUREKA.-Very large, leafy stock variety. Qt. $20 \mathrm{c}$; pk. $65 \mathrm{c}$.

EARLY SANFORD.—Early white flint variety for ensilage or grinding. Qt. $15 \mathrm{c}$; pk. $60 \mathrm{c}$. Write for prices on bushel lots.

\section{We Manufacture All Kinds of}

Team and Farm Wagion Wheels And furnish them tired, banded and boxed, with Concord axles, welded and set. Write for particulars

A. E. STEVENS \& CO., - Portland, Me. 


\section{Pop Corn}

TATTOOED YANKEE.-A great novelty, early and superior quality. Pkt. $10 \mathrm{c}$.

QUEEN'S GOLDEN.-A fine variety, large ears, pops perfectly white. Pkt. $10 \mathrm{c}$.

WHITE RICE.-One of the best. Pkt. $10 \mathrm{c}$; pt. $15 \mathrm{c} ;$ qt. $35 \mathrm{c}$.

GOLDEN TOM THUMB.-A great novelty. Stalks grow about eighteen inches high. Pkt. $10 \mathrm{c}$.

\section{Cucumbers}

EARLY CLUSTER.-Bears in clusters, early and productive. Pkt. 5c; oz. $10 \mathrm{c} ; 1-4 \mathrm{lb}$. $30 \mathrm{c}$.

EARLY SHORT GREEN.-Early and productive, about five inches long, dark green. Pkt. $5 \mathrm{c} ;$ oz. $10 \mathrm{c} ; 1-4$ 1b. $30 \mathrm{c}$.

WHITE SPINE IMPROVED.-A great bearer, an excellent variety for the table. Pkt. 5c; oz. $10 \mathrm{c} ; 1-4$ 1b. $30 \mathrm{c}$.

ALL SMOOTH.-New Variety. See novelty page.

DAVIS PERFECT.-See novelty page.

IMPROVED LONG GREEN.-Fruit above twelve inches long, tender and excellent. Pkt. 5c; oz. $10 \mathrm{c} ; 1-4$ lb. $35 \mathrm{c}$.

BOSTON PICKLING.-Splendid for pickles. Pkt. 5c; oz. $10 \mathrm{c} ; 1-4$ lb. $30 \mathrm{c}$.

\section{Endive}

GREEN CURLED.-One of the best salad plants. Pkt. 5c.

\section{Kale}

GREEN CURLED SCOTCH.-A round dwarf variety rarely exceeding eighteen inches in height but spreading out under good cultivation to three feet in diameter. Pkt. J̄c; oz. $10 \mathrm{c}$.

\section{Kohlrabi, or Turnip Cabbage}

EARLY I'URPLE.-Tender, best market sort Pkt. 5c; oz. $20 \mathrm{c}$.

\section{Lettuce}

BOSTON CURLED.-The best curled variety. Pkt. 5c; oz. $20 \mathrm{c}$.

BOSTON MARIET-Forms fine, perfect heads, crisp and tender, grows very compact, good for forcing. Plkt. 5c; oz. $15 \mathrm{c}$.

BIG BOSTON-Is of unusual size and solidity of head. Pkt. 5c; oz. 20c.

WHITE SEEDED TENNIS B.ML.-A fine early sort and very hardy. Pkt. 5c; oz. 15c.

BLACK SEEDED TENNIS BALL.-Fine for forcing. Pkt. $5 \mathrm{c}$; oz. $15 \mathrm{c}$.

EARLY CURLED SIMPSON.-Curled variety, fine for cutting. Pkt. 5c; oz. $15 \mathrm{c}$.

HANSON.-Large, solid heads and fine flavor. Pkt. 5c; oz. 15c ICEBERG.-Q u i c k growing, large heads. Pkt. 10c; oz. 20c.

WONDERFUI. - A large variety. Slow to run to seed. Pkt. 10c. BRITTLE-ICE (new) See norelty page.

NEIV GIANT GLACIER.-Large heads, extremely crisp. Plkt. $10 \mathrm{c}$.

MAI IIING.-See novelty page.

PRIZE HEAD.-Large, loose heads tinged with red; very fine. Pkt. $5 \mathrm{c}$; oz. $20 \mathrm{c}$.

CHOICE VARIETIES mixed in one package, try it. Pkt. 5c; oz. $15 \mathrm{c} ; 1-4$ lb. $40 \mathrm{c}$.

\section{Melon (Musk)}

ARLINGTON NUTMEG.-Fruit large, round flesh thick and sweet.

BANQUET.-(New). Medium size, best of all. Course netting, greenish flesh and delicious.

ROCIY FORD MUSI MELON.-The fruit is oval, slightly ribbed, densely covered with coarse, netting, greenish flesh and delicious flavor. Price each pkt. 5c; oz. $10 \mathrm{c}$. 


\section{Melon (Water)}

MOUNTAIN SWEET-One of the best for northern cultivation, oblong, fruit dark green.

COLES EARLY.-Extra early, best for New England.

VICK'S EARLY.-Very early, medium size, oblong, fine quality.

SWEET HEART.-This new melon is uniformly of good size, skin light green mottled. The bright red flesh is solid and sweet.

CITRON.-The standard for preserves.

COLORADO CITRON.-Fine for preserves. Price each, pkt. 5c; oz. 10c; 1-4 1b. $25 \mathrm{c}$.

\section{Martynia}

The pods when young and tender are used for pickles. Pkt. $10 \mathrm{c}$.

\section{Onions}

LARGE EARLY RED.-A close-grained, mildflavored variety. A good keeper. Pkt. 5c; oz. $20 \mathrm{c} ; 1-4$ lb. $60 \mathrm{c} ; 1 \mathrm{~b} . \$ 1.90$.

LARGE RED WETHERSFIELD.-Very large, of finest flavor, keeps well. Pkt. $5 \mathrm{c}$; oz. $20 \mathrm{c} ; 1-4$ lb. $65 \mathrm{c} ; 1 \mathrm{~b}$. $\$ 2.00$.

BURPEE'S YELLOW DANVERS.-One of the very best varieties for general crop. Succeeds well in New England. True stock. Pkt. 5c; oz. 15c; 1-4 lb. 50c; lb. \$1.75.

BEST YELLOW GLOBE DANVERS.-(True stock.) The best variety for general crop, an early, round variety yields large crops and keeps well. We ask attention to the seed we offer and recommend it as a superior quality. Pkt. 5c; oz. 20c;1-4 lb. $65 \mathrm{c} ; 1 \mathrm{~b} . \$ 2.25$.

BARLETTA.-Very early white onion, fine for pickles. Pkt. 5c; oz. $25 \mathrm{c}$.

PRIZE TAKER.-A large yellow globe onion, sweet, mild and tender. Pkt. 5c; oz. $25 \mathrm{c}$; 1-4 lb. $75 \mathrm{c}$.

EXTRA EARLY AUSTRALIAN YELLOW GLOBE ONION.-This extra early variety of onion grows to a large size, is very solid, skin is yellow, flesh white and very mild. Pkt. 10c; oz. 25c;1-4 1b. 65c.

\section{Onion Sets}

YELLOW SETS.-The best for general use. The small bulbs are used in the spring "or setting out, in place of sowing the seed, and produce large onions earlier than can be done by the seed. Qt. $25 \mathrm{c}$; if by mail, $35 \mathrm{c}$. per qt; peck $\$ 1.25$.

RED SETS.-Same price as above.

\section{Parsnips}

HOLLOW CROWN.-Good old sort, fine flavor.
LONG SMOOTH WHITE.-Smooth and quite large. Each, per pkt. 5c; oz. $10 \mathrm{c} ; 1-4 \mathrm{lb}$. $20 \mathrm{c} ; 1 \mathrm{~b} .50 \mathrm{c}$.

\section{Parsley}

EXTRA FINE CURLED.-Fine for garnishing. Pkt. 5c; oz. $10 \mathrm{c}$.

\section{Peas}

If by mail, add at the rate of 15c. per qt. LAXTONIAN. - See Novelty page. SUTTONS EXCELSIOR.-See novelty page. PRINCE EDWARD.- See novelty page. SENATOR.-See novelty page.

HANCOCK.-Very early and well-known variety. Pkt. $10 \mathrm{c}$; qt. $25 \mathrm{c}$; pk. $\$ 1.50$.

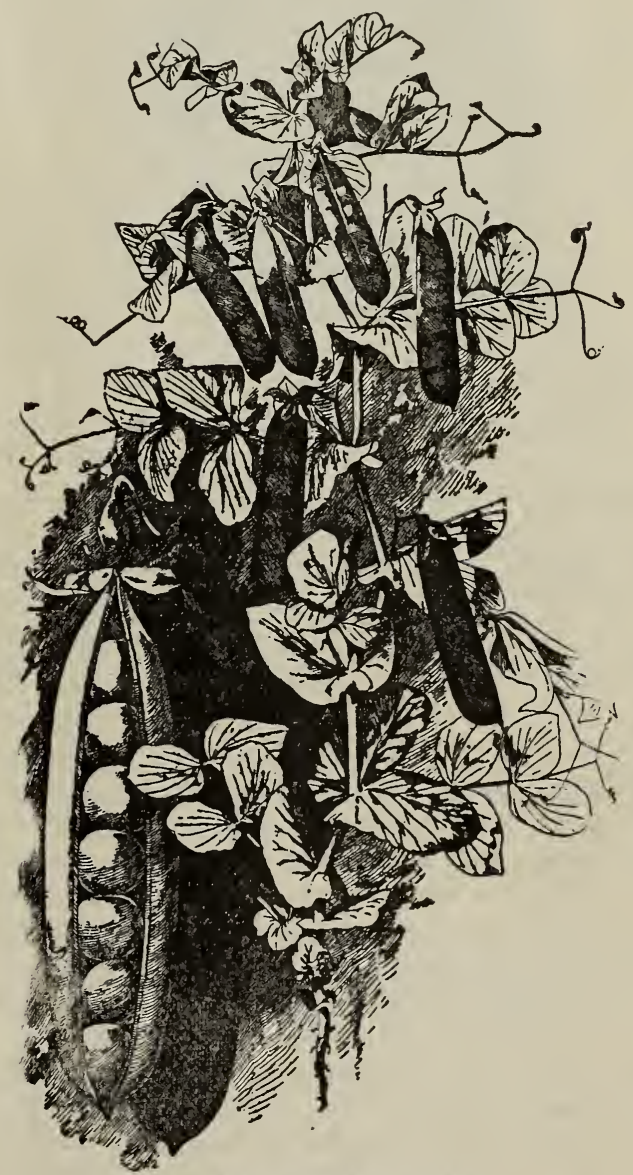

INOTT'S:EXCELSIOR PEA

NOTT'S EXCELSIOR.-A fine new extra early, dwarf wrinkled pea, producing in profusion long, handsome pods, closely packed with large peas of fine flavor. An improvement on American Wonder, being more vigorous and prolific, with larger pods and more peas. Height 15 in. Pkt. $10 \mathrm{c}$; pt. $15 \mathrm{c} ;$ qt. $30 \mathrm{c}$; pk. $\$ 2.00$. 
FIRST OF ALL.-A superior early variety, sweet and juicy, pods well filled. Height 2 ft. Pkt. $10 \mathrm{c} ;$ qt. $25 \mathrm{c} ;$ pk. $\$ 1.50$.

BURPEE'S BEST EXTRA EARLY.-One of the best of the early, round varieties. Pkt. $10 \mathrm{c} ;$ qt. $25 \mathrm{c} ;$ pk. $\$ 1.50$.

PHILADELPHIA EXTRA EARLY.-A standard extra early variety. Pkt. $10 \mathrm{c}$; qt. $25 \mathrm{c}$; pk. $\$ 1.50$.

THOMAS LAXTON.-A new extra early large podded pea, very hardy and productive. As early as the Gradus and the pods a little larger and a deeper green. Pkt. 10c; pt. $15 \mathrm{c}$; qt. $30 \mathrm{c} ; \mathrm{pk}$. $\$ 2.25$.

ALDERMAN.-A fine large pea of the Telephone type. Pkt. $10 \mathrm{c}$; pt. $15 \mathrm{c} ;$ qt. $30 \mathrm{c}$; pk. $\$ 2.25$.

BLISS EVERBEARING.-A splendid general cropper, with large, well-filled pods, very sweet. Height 2 ft. Pkt. $10 \mathrm{c}$; qt. $25 \mathrm{c}$; pk. $\$ 1.50$.

IMPROVED AMERICAN WONDER.-The earliest and very best wrinkled pea known, growing about 15 inches high, in productiveness, flavor and quality it is unsurpassed. Pkt. $10 \mathrm{c}$; pt. $15 \mathrm{c}$; qt. $30 \mathrm{c}$; pk. $\$ 2.00$.

CHAMPION OF ENGLAND.-An old favorite, rich flavored and very productive. Height, $4 \mathrm{ft}$ Pkt. $10 \mathrm{c}$; pt. $15 \mathrm{c}$; qt. $25 \mathrm{c} ;$ pk. $\$ 1.75$.

ADMIRAL DEWWY PEA.-With out exception the largest podded pea grown, a tremendous cropper, dark green pods, of excellent quality. Remarkably healthy and vigorous producing abundance of pods of very large size and well filled. Height $31-2$ feet. The very best of the late varieties. Pkt. $10 \mathrm{c}$; pt. $15 \mathrm{c} ;$ qt. $30 \mathrm{c} ;$ pk. $\$ 2.25$.

GRADUS OR PROSPERITY.-Large, handsome pods resembling Telephone in size and shape, well filled with large peas, ripening with the earliest, of vigorous habit, very quick to germinate and push to maturity. The best extra early wrinkled pea ever introduced. Height, 3 feet. Pkt. 10c; pt. $15 \mathrm{c} ;$ qt. $30 \mathrm{c} ;$ pk. $\$ 2.25$.

TELEPHONE.-Immensely productive, of the finest quality, pods of large size and filled with large, delicious peas. Plkt. 10c; pt. $15 \mathrm{c}$; qt. $25 \mathrm{c}$; pk. $\$ 1.7 \mathrm{o}$.

IMPROVED STRATEGEM.-The vines are strong and vigorous and covered with immense pods, filled with large, dark green peas of the finest quality. Pkt. $10 \mathrm{c}$; pt. $15 \mathrm{c}$; qt. $30 \mathrm{c} ;$ pk. $\$ 1.75$.

BLACK EYED MARROWFAT.-Large podded, prolific, capital for market. Plkt. $10 \mathrm{c}$; qt. $20 \mathrm{c} ;$ pk. $90 \mathrm{c}$.

\section{Pumpkins}

LARGE FIELD. - The common large yellow, good for stock. Pkt. 5c; oz. $10 \mathrm{c} ; 1-4 \mathrm{lb}$. $20 \mathrm{c} ; 1 \mathrm{~b} .40 \mathrm{c}$.

PUMPIIN, WINTER LUXURY.-We consider this the best pumpkin grown for making pies, medium in size, very finely netted, and in color it is a golden russet. Pkt. $5 \mathrm{c}$; oz. $10 \mathrm{c} ; 1-4$ lb. $25 \mathrm{c}$.

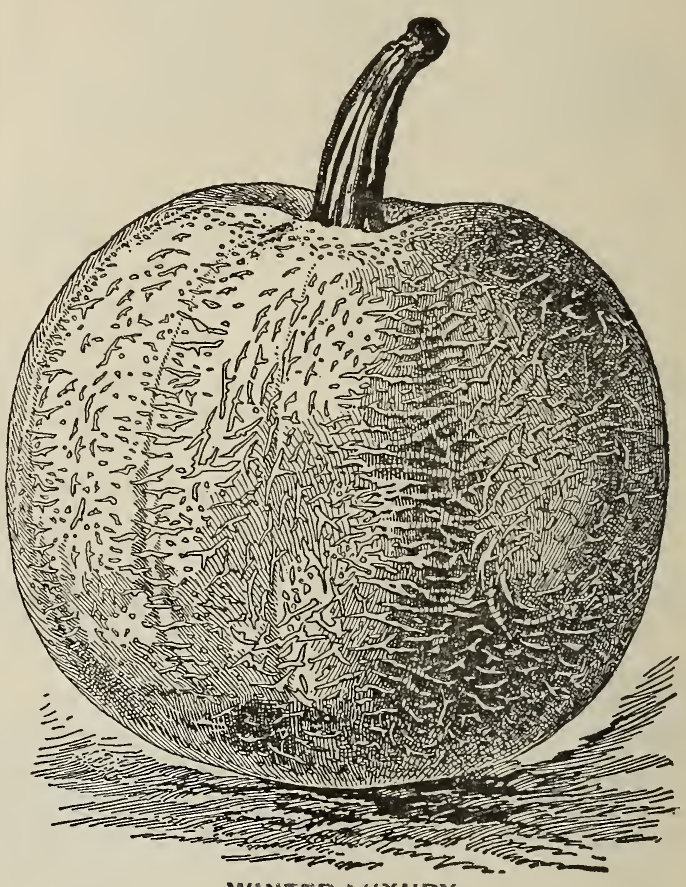

WINTER LUXURY

GLANT PUMPIINS MIXED.-All the known mammoth varieties, mixed. Pkt. $10 \mathrm{c} ; \mathrm{oz}$. $20 \mathrm{c}$.

GOLDEN OBLONG.-Fine for pies. Pkt. $5 \mathrm{c}$; oz. $10 \mathrm{c} ; 1-4$ lb. $30 \mathrm{c}$.

CHOICE MUXED.-Mixed in one package. Pkt. $5 \mathrm{c} ;$ oz. $10 \mathrm{c} ; 1-4$ lb. $20 \mathrm{c}$.

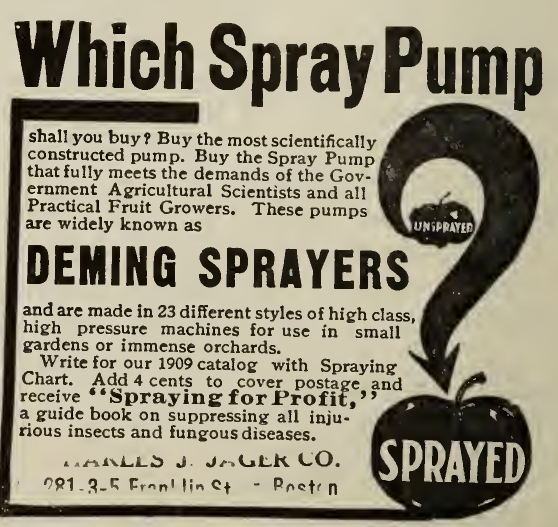


MAMMOTH MLXED.-See prize Pumpkin Contest.

SUGAR.-A small variety, fine-grained and sweet. Plit. 5c; oz. $10 \mathrm{c} ; 1-4$ lb. $25 \mathrm{c}$.

LARGE CHEESE.-The best variety for cooking purposes. Pkt. $5 \mathrm{c}$; oz. $10 \mathrm{c}$; $1-4 \mathrm{lb} .20 \mathrm{c}$; lb. $45 \mathrm{c}$.

PUMPLIN, KING OF MAMMOTHS.-Grows to enormous size, a splendid keeper, always a prize winner at fairs. Pkt. $10 \mathrm{c}$; oz. $20 \mathrm{c}$.

\section{Pepper}

SWEET MOUNTAIN.-Large and fine. Pkt. 5 c; oz. 25 c.

LARGE BELL.-Large, bright red, a handsome variety Pkt. $5 \mathrm{c}$; oz. $30 \mathrm{c} ; 1-4 \mathrm{lb} . \$ 1.00$.

FINE CHOICE VARIETIES.-Mixed in one package. Plit. 5c.

\section{Radish}

VICKS SCARLET GLOBE.-Best of the globe varieties.

CRIMSON GIANT GLOBE.-Large size, remains solid a long time.

FRENCH BREAKFAST.-A variety of quick growth, mild tender, olive-shaped.

EARLY SCARLET GLOBE.-Small top, very crisp and tender.

WHITE TIPPED SCARLET GLOBE.-Early crisp and tender.

EARLY WHITE TURNIP.-Early, pure white, quick growing.

EARLY SCARLET TURNIP.-Round, scarlet, mild and crisp.

LONG SCARLET.-Very long and crisp, a standard variety.

CHARTIER.-Long crimson, tipped with white. ICICLE.-A handsome, first class early long variety, snow white in color. Attractive and excellent in every way.

Price each, pkt. 5c; oz. 10c; 1-4 lb. 25c.

\section{Salsify, or Vegetable Oyster}

MAMLOTH SANDWICH ISLAND.-The roots are very large and very delicate in flavor. Pkt. $5 \mathrm{c}$; oz. $15 \mathrm{c}$.

\section{Spinach}

LONG STANDING.-One of the best varieties, dark green, slow in running to seed. Pkt. $5 \mathrm{c}$; oz. $10 \mathrm{c}$; $1-4$ lb. $15 \mathrm{c}$; 1b. $35 \mathrm{c}$.

VICTORIA SPINACH.-We can recommend this variety as very large, thick dark green leaf. As early as any other, but distinguished for its long, branching qualities. Pkt. $5 \mathrm{c}$; oz. $10 \mathrm{c}$; $1-4$ lb. $20 \mathrm{c}$; lb. $35 \mathrm{c}$.

\section{Squash}

MAMMOTH SUMMER CROOKNECK.-Early, large fine for summer use. Pkt. $5 \mathrm{c}$; oz. $10 \mathrm{c} ; 1-4$ lb. $25 \mathrm{c}$.

\section{NEW MAMMOTH WHITE BRUSH SCALLOPED}

- The earliest summer sort. Pkt. 5c; oz. $10 \mathrm{c} ; 1-4$ lb. $25 \mathrm{c}$.

EARLY PROLIFIC ORANGE MARROW.-No variety can compete with it for earliness, very productive. Pkt. $5 \mathrm{c}$; oz. $10 \mathrm{c} ; 1-4 \mathrm{lb}$. $30 \mathrm{c} ; 1 \mathrm{~b} .80 \mathrm{c}$.

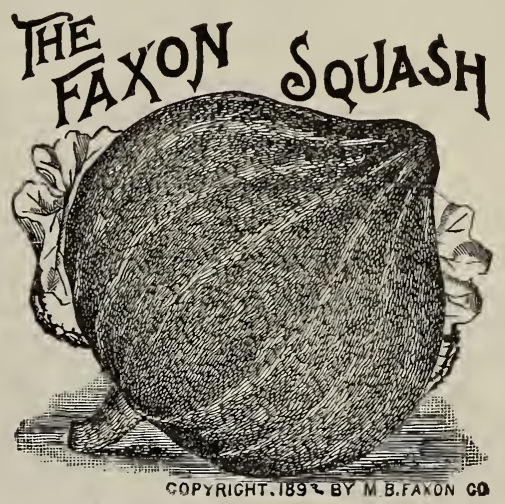

BOSTON MARROW.-A standard early fall squash, rich orange color, sweet and dry. Pkt. $5 \mathrm{c}$; oz. $10 \mathrm{c}$; $1-4$ lb. $25 \mathrm{c}$; 1b. $75 \mathrm{c}$.

HUBBARD.-Standard winter squash, an excellent keeper. Pkt. 5c; oz. $10 \mathrm{c} ; 1-4 \mathrm{lb}$. $25 \mathrm{c} ; 1 \mathrm{~b} .85 \mathrm{c}$.

MARBLEHEAD.-An excellent winter variety, remarkably sweet and dry. Pkt. $5 \mathrm{c} ; \mathrm{oz}$. $15 \mathrm{c} ; 1-4$ lb. $30 \mathrm{c}$; 1b. $80 \mathrm{c}$.

GOLDEN HUBBARD.-A true Hubbard except in color which is a beautiful orange red. Pkt. 5c; oz. $10 \mathrm{c}$; $1-4$ lb. $30 \mathrm{c}$; 1b. $85 \mathrm{c}$.

WARTED HUBBARD SQUASH.-This excellent Strain of Hubbard squash grows to a large size, is blackest green in color, with warty knobs all over it. Pkt. 5c; oz. 10c; 1-4 lb. $30 \mathrm{c} ; 1 \mathrm{~b} .85 \mathrm{c}$.

DUNLAP'S EARLY MARROW.-No variety can compete with it for earliness, excellent quality and a good keeper. Pkt. 5c; oz. $15 \mathrm{c} ; 1-4$ lb. $30 \mathrm{c}$; lb. $80 \mathrm{c}$.

THE FAXON.-Matures early, one of the best fall and winter varieties, of medium size sweet and dry. Pkt. $5 \mathrm{c}$; oz. $10 \mathrm{c} ; 1-4 \mathrm{lb}$. $30 \mathrm{c} ; 1 \mathrm{~b} .80 \mathrm{c}$.

DELICIOUS.-See Novelty page.

MAMMOTH WHALE.-Largest and heaviest of all squashes, fine for exhibition. Pkt. $10 \mathrm{c}$.

\section{Tomato}

DWARF CHAMPION.-A very early variety, beautiful, solid fruit, fine flavor. Pkt. 5c; oz. $25 \mathrm{c}$. 
NEUV STONE.-Large, perfectly smooth, scarlet, one of the best. Pkt. 5c; oz. $25 \mathrm{c} ; 1-4 \mathrm{lb}$. $70 \mathrm{c}$.

LIVINGSTON'S FAVORITE. - Bright red, good size and smooth. Pkt. 5c; oz. $20 \mathrm{c}$.

LIVINGSTON'S PERFECTION.-Early, large and very productive, ripens evenly. Pkt. $5 \mathrm{c} ; \mathrm{oz} .25 \mathrm{c}$.

TROPHY.-A standard sort and good in every way, Pkt. $5 \mathrm{c}$; oz. $25 \mathrm{c}$.

LIVINGSTON'S BEAUTY.-Very glossy, crimson in color, slight tinge of purple, early free from rot, bears handling remarkably well. Pkt. $5 \mathrm{c} ;$ oz. $25 \mathrm{c}$.

CHALK'S EARLY JEWEL.-The earliest tomato in cultivation. Large, smooth and fine flavor, flesh bright scarlet. Pkt. 10c; oz. $30 \mathrm{c}$.

BURPEE'S EARLIEST PINK.-Best of the early pink varieties. Pkt. $10 \mathrm{c}$; oz. $30 \mathrm{c}$.

JUNE PINK.-See Novelty page.

PONDEROSA.-Very large, solid and of good flavor. Pkt. $10 \mathrm{c}$; oz. $30 \mathrm{c}$.

ADMIRAL DEWEY.-(New). See Novelty page. EARLIANA.-Best early. See novelties.

YELLOW PEAR.-For Preserving. Pkt. 5c.

GOLDEN QUEEN.-A large smooth yellow variety. Pkt. $5 \mathrm{c}$; oz. $30 \mathrm{c}$.

TWENTY CHOICE VARIETIES MIXED.- Including all the above varieties and others. Pkt. 5c; oz. 20c; 1-4 lb. $65 \mathrm{c}$.

\section{Turnips}

EARLY RED PURPLE TOP.-Very early, sweet, mild and a rapid grower. Pkt. 5c; oz. $10 \mathrm{c} ; 1-4$ lb. $20 \mathrm{c}$; 1b. $45 \mathrm{c}$.

IVHITE EGG.-Excellent early variety, egg shaped, mild flavor. Pkt. 5c; oz. $10 \mathrm{c} ; 1-4$ lb. $20 \mathrm{c} ; 1 \mathrm{~b} .50 \mathrm{c}$.

EXTRA EARLY IVHITE MILAN. - The best of the white varieties early and sweet. Pkt. $5 \mathrm{c} ;$ oz. $10 \mathrm{c} ; 1-4 \mathrm{lb} .25 \mathrm{c}$.

EARLY RED MILAN.-Best of the red top varieties. Early and sweet. Pt. 5c; oz. $10 \mathrm{c}$; 1-4 lb. $25 \mathrm{c}$.

\section{Swede, or Ruta Baga}

IMPROVED PURPLE TOP.-Very early, free growing, the best Purple Top Swede in cultivation. Pkt 5c; oz. $10 \mathrm{c} ; 1-4 \mathrm{lb} .20 \mathrm{c} ; 1 \mathrm{~b}$. $50 \mathrm{c}$.

CARTER'S IMPERIAL.-Very popular, flesh very solid and a fine keeper. Pkt. 5c; oz. $10 \mathrm{c} ; 1-4$ lb. $20 \mathrm{c}$; 1b. $50 \mathrm{c}$.

SKIRVING'S PURPLE TOP.-A standard variety, hardy and productive. Pkt. 5c; oz. $10 \mathrm{c} ; 1-4$ lb. $20 \mathrm{c}$; 1b. $50 \mathrm{c}$.

LAING'S PURPLE TOP.-A large early sort of fine quality, flesh yellow, sweet and well flavored Pkt. 5c; oz. $10 \mathrm{c} ; 1-4$ lb. $20 \mathrm{c}$; 1b. $45 \mathrm{c}$.

LARGE WHITE FRENCH.-The best of the white varieties, sweet and excellent. Pkt. $5 \mathrm{c}$; oz. $10 \mathrm{c} ; 1-4$ lb. $20 \mathrm{c}$; 1b. $50 \mathrm{c}$.

\section{Herbs}

SAGE

SUMMER SAVORY

SWEET MARJORAM

LAVENDER

THYME

Each, per pkt. $5 \mathrm{c}$. oz. $20 \mathrm{c}$.

CHIVES.-Roots by mail prepaid $20 \mathrm{c}$.

\section{Lawn Seeds}

EVERGREEN LAIVN SEED-A superior mixture for lawns, tennis courts, etc. Gives a fine, smooth, velvet sward within a few weeks after sowing. Pt. $12 \mathrm{c}$; qt. $25 \mathrm{c} . \mathrm{pk}$. $\$ 1.50$.

KIMBALL'S VELVET LAIVN GRASS MIXTURE.-A very fine mixture and will give general satisfaction. Pt. $12 \mathrm{c} ; \mathrm{qt} .20 \mathrm{c}$; pk. $\$ 1.35$.

\section{"Be Good" to Your Horses}

\section{Use Frazer's Axle Grease} and make it easy for them.

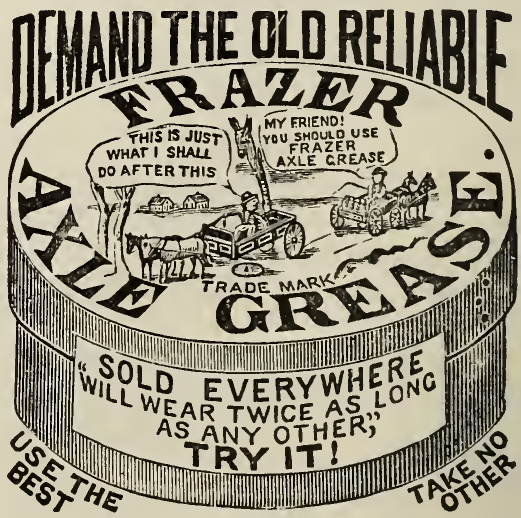

Recognized as the Standard Axle Grease of the United States.

Many Thousand Tubs of this Grease are sold weekly to the truckmen of New York City. Their Trucks are loaded heavily and a saving of both time and money is made, one greasing lasting two weeks or longer.

Ask your dealer for FRAZER'S with label on. It saves your horse labor, and you too. Sold everywhere.

Frazer Lubricator Co., 83 Murray St., N. Y. 
SHADY SPOT LAWN SEED.-For shady places and under trees. Pt. $15 \mathrm{c}$; qt. $30 \mathrm{c}$.

WHITE CLOVER. - 20c pound.

KENTUCKY BLUE GRASS.-For lawns, $20 \mathrm{c} \mathrm{lb.}$

\section{Farm Seeds}

We wish our customers to know that we deal only in the very highest grade of grass seed, quality and purity our first consideration. Every farmer has learned to his sorrow that the ordinary and low priced grass seed contain more or less foul weeds, chaff, sand etc. Our choice Timothy and Red Clover guaranteed $99 \%$ to 99.5 $\%$ pure U. S. Government test.

TIMOTHY. $-7 \mathrm{c}$ lb. and $\$ 2.35$ to $\$ 2.75$ bu.

RED CLOVER. $-18 \mathrm{c} 1 \mathrm{~b}$.

CRIMSON CLOVER.-12c $\mathrm{lb}$.

ALSIKE CLOVER, FANCY RED TOP RECLEANSED, ORCHARD GRASS.-

HUNGARIAN.-5c. $1 \mathrm{~b} ; 45 \mathrm{c}$. pk.

JAPANESE MLLET.-10c. lb; $\$ 8.00$ per 100 lbs.

BARLEY.- $4 \mathrm{c} .1 \mathrm{~b}$.

JAPANESE BUCIWHEAT. - $50 \mathrm{c}$. pk.

SELECTED SEED OATS.-

Prices on above Field Seeds, etc., subject to market fluctuations and are net cash, no discount. Samples on application. Write for bushel rates.

DWARF ESSEX RAPE.-Per pound 12c.

\begin{tabular}{ll}
\multicolumn{2}{c}{ Field and Ensilage Corn } \\
LEAMING & EARLY SANFORD \\
LONGFELLOW & RED COB \\
SUVET FODDER & EUREKA \\
\hline
\end{tabular}

All at the lowest market rates and the best quality. Write for prices for bushel rates.

\section{Odorless Lawn and Garden Fertilizer} ODORLESS LAWN AND GARDEN FERTILIZER.-This superior dressing is so prepared that it acts gradually throughout the season, and produces a luxuriant growth. It is far superior to strawy manure, contains no foud weeds and less expensive and is easily applied at all seasons. An excellent fertilizer for lawns, kitchen gardens, fruit trees, flower beds and house plants. Price 5c. $\mathrm{lb} ; 10$ lb. bag $45 \mathrm{c} ; 25 \mathrm{lb}$. bag $\$ 1.00 ; 50$ lb. bag $\$ 1.50 ; 100$ lb. bag $\$ 2.50$. POTATO FERTILIZER.

CORN FERTILIZER.

GRAIN AND GRASS FERTILIZER.

Fertilizer for farm and garden in 5, 10, 25, 50 and 100 pound bags.

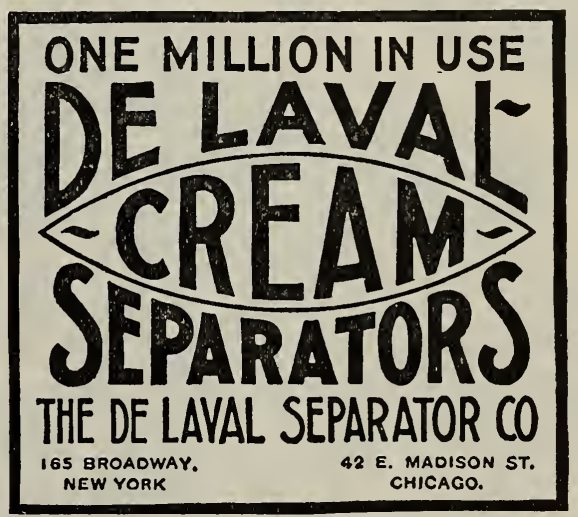

PRIZE PUMPKIN CONTEST. Five Beautiful Premiums Offered for Prizes

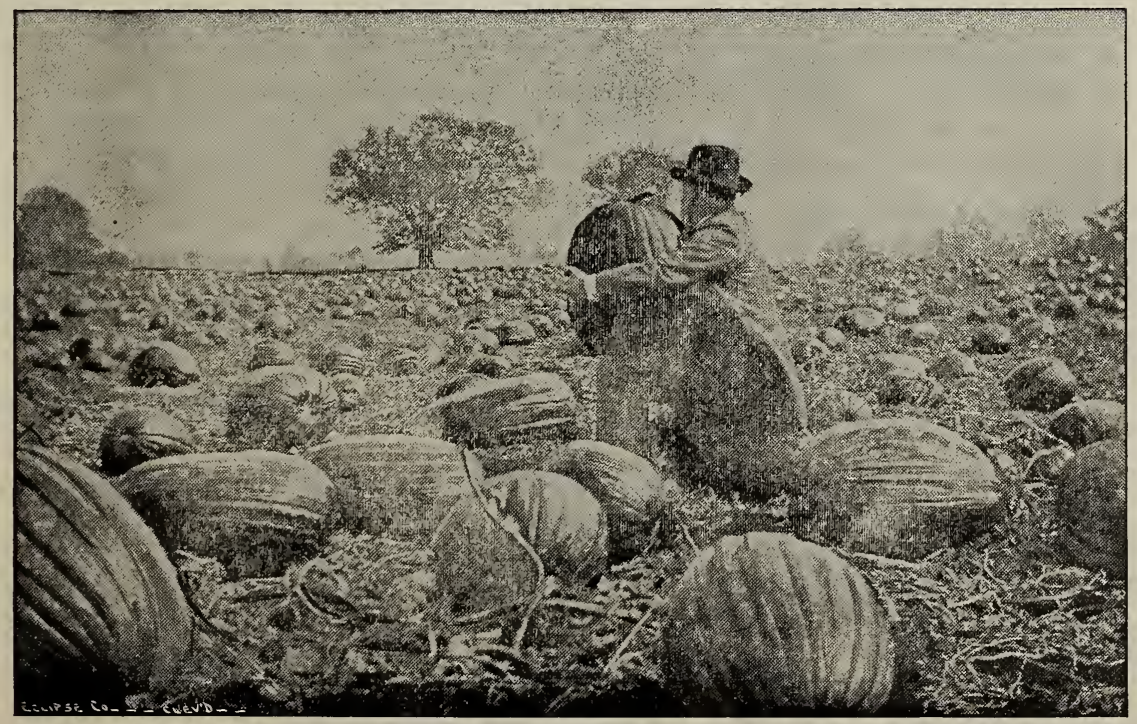

We want all of our customers to enter this contest and we offer Five Beautiful Silver Premiums for the five largest pumpkins grown from our Prize Pumpkin mixture. Our mixture contains all of the leading American and foreign varieties of Mammoth pumpkins, some of the seeds were taken from specimens weighing over 150 pounds. It is the best mixture you can possibly get and if you want to grow something big for exhibition purposes this is just what you want.

Contest closes Nov. 30. Write us before that date giving the weight of your largest pumpkin.

Large packets 10c 


\section{Choice Flower Seeds, Hardy Shrubs and Bulbs}

\section{Asters}

Early Snowdrift.-See novelty page.

Lavender Gem.- See novelty page.

Vick's New Branching.-Magnificent large flowers borne on long stems. The long broad petals are frequently twisted and curled, giving the blossom the appearance of a large, graceful chrysanthemum. Finest mixed, $10 \mathrm{c}$. White, Pink, Crimson and Lavender, $10 \mathrm{c}$. each.

Pyramidal.-Large extra double, fine mixed, $10 \mathrm{c}$.

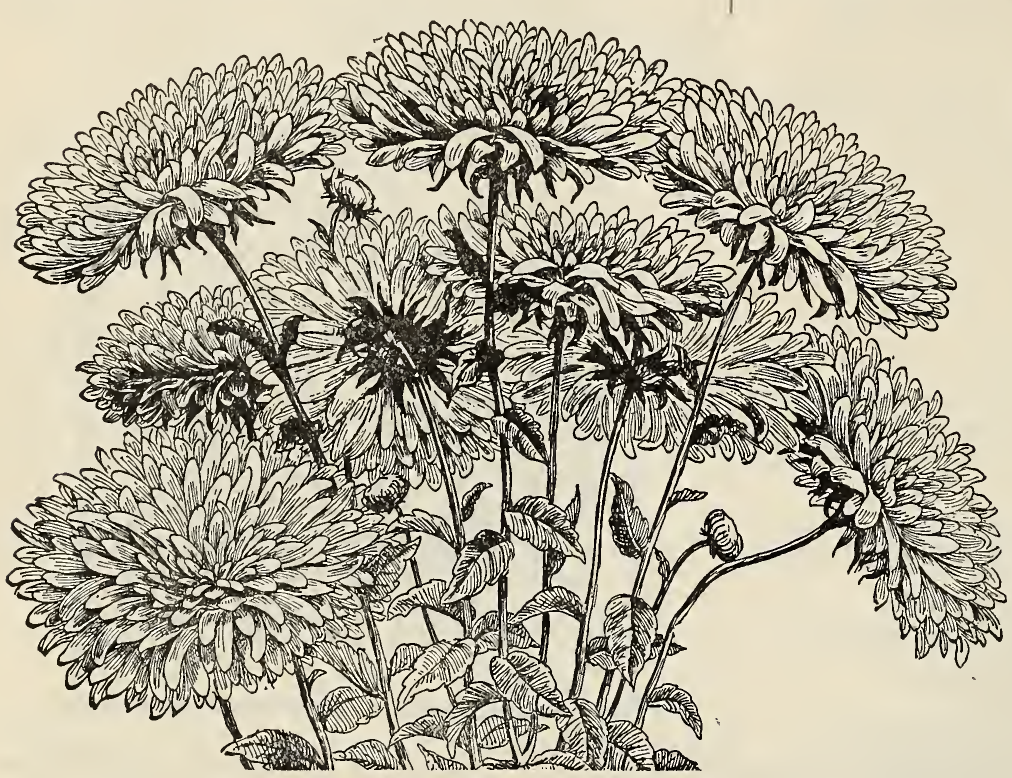

Jewel or Ball.-A magnificent class, with perfectly round flowers, about 2 1-2 inches in diameter, borne on long stems; petals incurved; excellent for cutting, mixed $10 \mathrm{c}$.

Paeony Perfection.-A fine class with large, double, incurved flowers of great beauty, Choice mixed, $10 \mathrm{c}$.

Ostrich Feather.-A new class of asters, with long curved, fringe-like petals, mixed $10 \mathrm{c}$. White, $10 \mathrm{c}$.

Hohenzollern.- Superb new branching class with enormous flowers on long stems. Pkt. $10 \mathrm{c}$.

Mignon.-A valuable class resembling in habit, height and form the Victoria, mixed, $10 \mathrm{c}$.

Truffant's Imbricated Pom. Pom.-Very fine, small, flowered sort, excellent for cutting, mixed, $10 \mathrm{c}$.

Finest Mixed.-This collection includesall colors and shades of many choice varieties, $10 \mathrm{c}$.

Choice Mixed.-A fine mixture, $5 \mathrm{c}$.

Ageratum blue.-Freeflowering; good for beds and pots, $5 \mathrm{c}$.

Acroclinium.-One of the handsomest everlastings, and used extensively in bouquet of dried flowers, mixed, $5 \mathrm{c}$.
New Comet.-These varieties make a grand display, often carrying thirty-five flowers on one plant, curled and twisted like Japanese chrysanthemums, mixed, $10 \mathrm{c}$. White $10 \mathrm{c}$.

Semple's Branching.-A new American strain, producing handsome, large, double flowers on long stems. Finest mixed, 5c.

Queen of the Market.-Very early, many beautiful colors mixed, $5 \mathrm{c}$.

German Globe.-An early variety, choice mixed of many colors, $5 \mathrm{c}$.

Chrysanthemum Flowered.-Very beautiful the flowers are exceedingly large and very double, mixed, $10 \mathrm{c}$.

Victoria.-One of the best and most popular asters grown. Forms a handsome, pyramidal bush, with perfectly double imbricated flowers on long stems, mixed $10 \mathrm{c}$ Pure white, very fine, $10 \mathrm{c}$.

Crown or Cocardeau.-Large double flowers, with white centres, mixed $10 \mathrm{c}$.
Agrostemma.-Attractive, free-flowering plants, of easy culture and excellent for cutting, mixed, $5 \mathrm{c}$.

Alyssum.-Sweet scented, white flowers, 5c.

Amaranthus.-Highly ornamented foliage and flowering plants of easiest culture. Annual, mixed, $5 \mathrm{c}$.

Ammobium, Grandiflorum.-Large pure white everlasting flower. Annual, $5 \mathrm{c}$.

Antirrhinum.-One of the most beautiful and useful border plants. Half-hardy perennial mixed, $5 \mathrm{c}$.

Bachelor's Buttons.-Emperor William, a fine deep blue, $5 c$.

Bachelor's Buttons.-Various colors mixed, 5c. Double Mixed.-All colors, $5 \mathrm{c}$.

Aquilegia.-(Columbine) . .Popular free flowering plants, blooming profusely through the spring and early summer. Hardy perennial mixed, $5 \mathrm{c}$.

Balsam.-Superb, fine double mixed, 10c.

Balsam.-Fine mixed, $5 \mathrm{c}$. 
California Poppy-Hardy annual, profusion of rich, single, yellow flowers. Mixed, ว̄c.

Mandarin.-Deep yellow, $5 \mathrm{c}$.

Calenclula.-(Marigold) Prince of Orange, color intense orange, blooms all summer, $5 \mathrm{c}$.

Meteor, beautifully striped, $5 \mathrm{c}$.

Choice mixed, 1-2 oz. $15 \mathrm{c}$; pkt. 5c.

Canterbury Bells.-Best mixed, $5 \mathrm{c}$.

Coreopsis.-All shades of yellow, orange and brown, 5c.

Coronata. Large, fine yellow, $5 c$.

Drummondi. Large yellow, red spots, 5c.

Sunshine. See Novelty page.

Canary Bird Flower.-A beautiful climber with bright yellow flowers, $10 \mathrm{c}$.

Candytuft, White Queen.-A mass of white flowers, $5 \mathrm{c}$.

Finest mixed, all colors, 5̣c.

Empress. Large flowering white, $10 \mathrm{c}$.

Camms.-Handsome foliage, choice mixed, 5c.

Camation Marguerite.-A very 'arge percentage of the flowers come double and of good size, fine form and great beauty. They begin to bloom four months from the time seeds are sown. Finest mixed, $10 \mathrm{c}$.

Chrysanthemum.-Glorious and snowy annual, are easily raised from seed, fine mixed, $5 \mathrm{c}$.

Celosia.-(Cockcomb.) Dwarf mixed, strikingly brilliant, $5 \mathrm{c}$.

Clarkia.-Showy, hardy annuals of easy cultivation, mixed, $5 c$.

Cosmos.-Mammoth California, mixed, $10 \mathrm{c}$.

Cobaea Scandens. - A climber of rapid growth. Flower first season if sown early, $10 \mathrm{c}$.

Cuphia.-(Cigar Plant.) A fine border plant, bright scarlet, $10 \mathrm{c}$.

Cypress Vine.-Choice mixed, j̀c.

Dahlia.-Single mixed, many colors, 5c.

Dahlia.-Double mixed, $10 \mathrm{c}$.

Dianthus.-(China Pink.) Finest mixed, double in great variety of colors, $5 \mathrm{c}$.

Heddewigi (Japan Pink) best double, 5c.

Datura.-('Trumpet Flower.) Handsome, bushy plants, covered with deliciously fragrant trumpet-shaped flowers, until late in the fall, mixed, $5 \mathrm{c}$.

Dolichos.-(Hyacinth Bean.) A rapid climber, with clusters of white or purple flowers, 5c.

Eschscholtzia.-Fine for edgings, 5c.

Forget-Me-Not.-(Mosotis.) Beautiful little plants, with bright, starlike flowers: useful for cutting. Succeed best in moist situations. Half hardy perennial, $10 \mathrm{c}$.

Gaillardia.-Greatly admired, blooming from July until frost, choicest mixed, $5 \mathrm{c}$.

Gilia.-Handscme plants with showy flowers. Hardy annual. Finest mixed, in great variety, 5̄c.
Godetia.-Profuse blooming plants, very showy, deserving more extensive cultivation, $5 \mathrm{c}$.

Gourds.-Ornamental climbers, varieties of singular shaped fruit, mixed, $5 c$.

Orange shape, 5c.-Egg shape, 5c.

Grasses.-Ornamental, all the best mixed varieties, $5 \mathrm{c}$.

Gypsophila.-(Baby's Breath.) Fine to mix with bouquets, $5 \mathrm{c}$.

Helianthus.-(Sunflower.)

Stella new, shining yellow with black center, $5 \mathrm{c}$.

Chrysanthemum, Flowered Sunflower, very double, a truly beautiful variety, $10 \mathrm{c}$.

New Mammoth Russian ,very large, single, $5 c$.

White Beauty, Mammoth heads, white seeds, $5 c$.

Many fine varieties mixed, $5 c$.

Hollyhock.-One of the oldest garden favorites, which ranks among the finest of our autumn flowers. The beautiful flowers of almost every shade and color, on the tall spikes, are very striking, $5 c$.

Humulus Japonica.-(Japan Hop.) Rapid sum* mer climber, foliage very luxuriant, $5 \mathrm{c}$.

Ice Plant.-Pretty trailing plant, with thick succulent foliage covered with transparent globules. Tender annual, 5c.

Kochia or Mexican Fire Plant.-Pkt. $5 \mathrm{c}$.

Larkspur.-Annuals of great beauty, stock flowered all colors, mixed, 5c.

Double Rocket, choice mixed, 5c.

Hyacinth, flowered, choice mixed, 5c.

Lobelia.-Free flowering and of easy culture, fine for borders, baskets and vases, $10 \mathrm{c}$.

Crystal Palace, compact, dark blue, fine, $10 \mathrm{c}$.

Lupins.-Desirable plants for every garden, hav= ing long spikes of bright colored flowers, mixed, $5 c$.

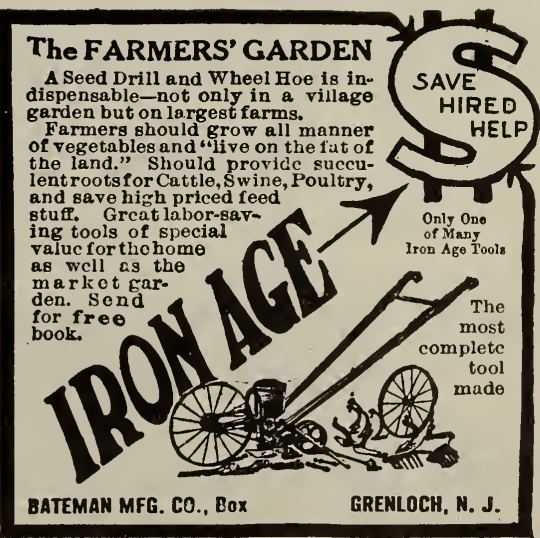


Marigold.-(African.) Planted by everyone, larger flowers than the French, mixed, $5 \mathrm{c}$. French double dwarf, finest mixed choice, 5 c.

Mixed, all kinds, $5 \mathrm{c}$.

Marvel of Peru.-(Four o'clock.) Brilliant, does well in any location, $5 \mathrm{c}$.

Mignonette.-Sweet-scented, large flowering, per oz. $15 \mathrm{c}$; pkt. $5 \mathrm{c}$.

Golden Queen, flowers very large and very fragrant, $10 \mathrm{c}$.

Matchet, fine for pot culture, $10 \mathrm{c}$.

Morning Glory.-Splendid climbers, profusion of bloom, 12 colors, $5 \mathrm{c}$.

Double Mixed.-Many colors, $5 \mathrm{c}$.

Imperial Japanese, of exquisite beauty and enormous size, $10 \mathrm{c}$

Dwarf, showy plants, with handsome, large richly-colored flowers, mixed, 5c.

Moonflower.-A beantiful climber, $10 \mathrm{c}$.

Mimulus.-(Monkey Flower.) They bloom early from seed, and are treated as annuals, mixed, $5 c$.

Nicotina.-Fragrant annual with clusters of white, tube-shaped flowers, 5c.

Nigela.-Love in the mist, כ̄c.

\section{Tall Nasturtium}

Our seeds of these popular flowers have gained a reputation for brilliancy and variety of color, form and substance of flower, which cannot be surpassed. In our mixture which we make up from separate and distinct sorts will be found a very great variety of most beautiful colors. Choice mixed. Pkt. 5c; oz. 10c; 1-4 1b. 30c.

Extra choice mixed. Plit. 5c; oz. 15c; 1-4 lb. $35 \mathrm{c}$.

Rainbow mixture. Pkt. 10c; oz. 20c; 1-4 lb. $45 \mathrm{c}$.

Lobb's.-This magnificent climber is of unusual vigorous growth, with beautiful foliage and splendid large flowers in the richest and most brilliant colors. Mixed, oz. $15 \mathrm{c} ; \mathrm{pkg}$. $10 \mathrm{c} ; 1-4 \mathrm{lb}, 40 \mathrm{c}$.
Dark crimson, scarlet, deep maroon, yellow, violet, bluish rose, striped, rose, each, $5 \mathrm{c}$.

Collection of seven tall varieties for $25 \mathrm{c}$.

Madame Gunter's Hybrid Varieties. - The foliage is mostly dark and forms a striking contrast with the rich co'ors and shades, many of which are new to this family and almost impossible to describe. Finest mixed, oz. $15 \mathrm{c}$; pkt. $10 \mathrm{c}$.

For other varieties see Novelty page.

\section{Dwarf Nasturtium}

Prize mixed dwarf varieties, embraces all the best colors. Oz. $15 \mathrm{c}$; pkt. 5̌c.

Choice mixed, oz. $10 \mathrm{c}$; plit. $5 \mathrm{c} ; 1-4$ lb. $30 \mathrm{c}$.

King of Tom Thumb, oz. 15c; pkt. $5 \mathrm{c}$.

New Chameleon, a grand new variety, flower varying in color, pkt. $10 \mathrm{c} ; 0 \mathrm{z} .20 \mathrm{c}$.

Dark leaved sorts, mixed. Pkt. 5c; oz. 10c.

Spotted varieties, mixed. Pkt. 5c; oz. 10c.

Empress of India, best brilliant scarlet. Pkt. 10c.

One horse is as good as two when
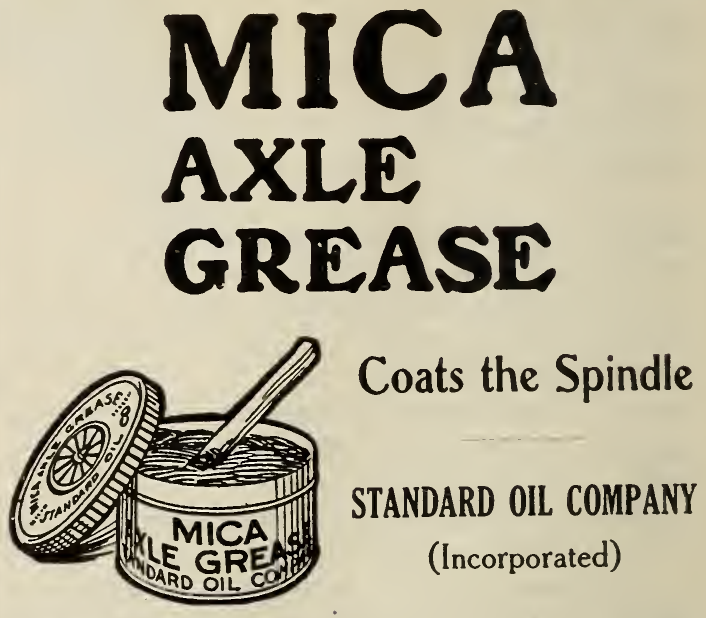

If Your Land Is Sour or Run Out Use

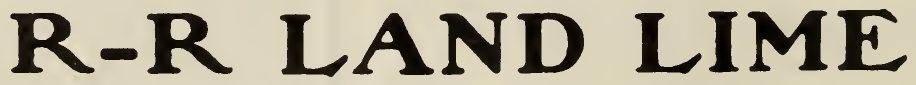

A High Calcium Iime in Powder form, ready to apply to the land. No waste of time, labor or material.

In All Spraying Mixtures Use PINE CONE HYDRATED LIME

Ready for immediate use-no slacking required-no clogging of noz\%les-economical-convenient.

ROCKLAND--ROCKPORT LIME CO., Rockland, Maine 


\section{Pansies}

Bugnots.-This is the finest strain known. Finest mixed, $15 \mathrm{c}$.

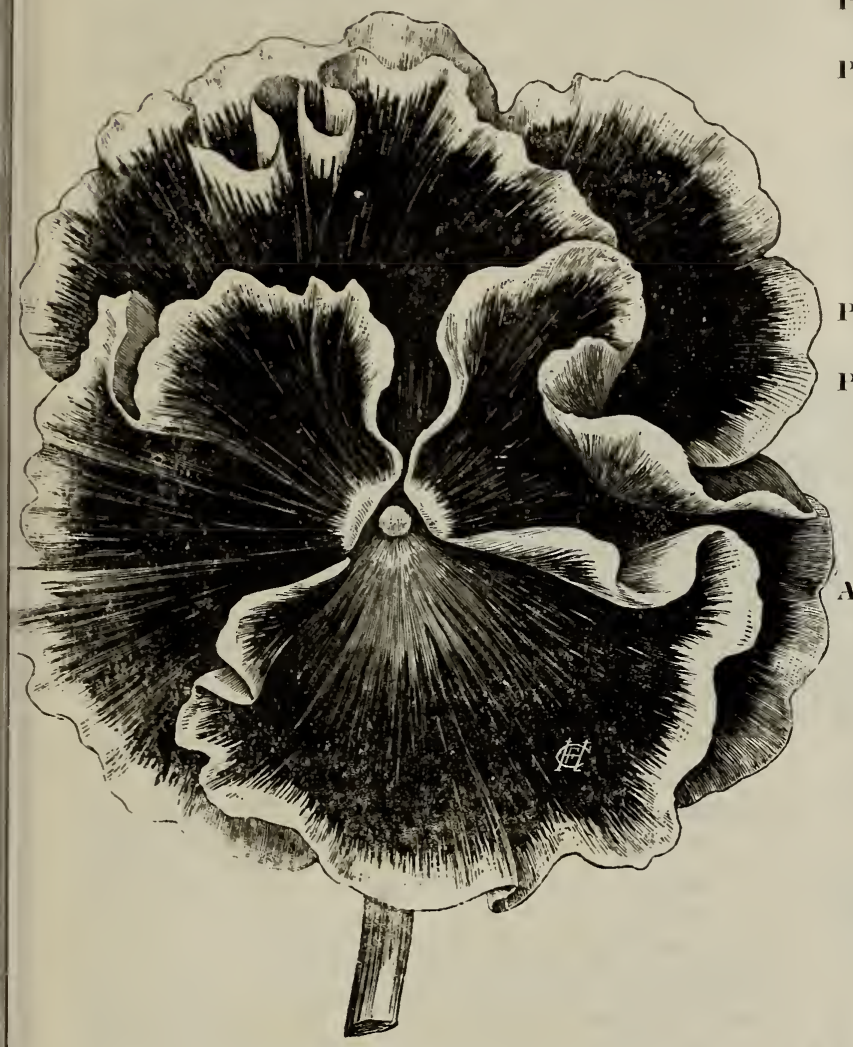

Odier.-Superb flowers of fine form and beautifully blotched, choice mixed, $10 \mathrm{c}$.

Trimardeau or Giant.-Extra choice strain of vigorous growth and flowers of enormous size, $10 \mathrm{c}$.

Cassier Giant.-Large flowers, a rich showy strain, choice mixed, $10 \mathrm{c}$.

French mixed.-A fine mixture in a great variety of choice colors, $10 \mathrm{c}$.

Giant Royal Show.-This is the finest mixture ever produced and of enormous size, $15 \mathrm{c}$.

Good Mixed.-Fine showy flowers, 5c; 1-4 oz. $50 \mathrm{c}$.

Special Mixed.-The best strain of large flowering sorts from the leading European growers; a grand variety, finest mixed, $15 \mathrm{c}$.

Bugnot, Cassier, Odier and Trimardeau mixed, large pkt. $15 \mathrm{c}$.

Snow Queen.-A beautiful large white, $10 \mathrm{c}$. Golden Yellow, King of the Blacks, Violets, Shining Red, Striped, Pure Yellow, Wine Red, Light Blue, Dark Blue, Black, Pure White, Red, Purple and Golden Yellow, Golden Bronze, Gold Bordered, each, pkt. $10 \mathrm{c}$.
Masterpiece.-New. See Novelty page.

Madame rerret.-Very fine, $15 \mathrm{c}$.

Portulaca.-Valuable for bedding, show? colors, mixed, $5 \mathrm{c}$.

P'etunia.-Finest single varieties carefully mixed, $5 \mathrm{c}$.

Finest mixed, colors mixed in great variety, $10 \mathrm{c}$.

Large flowered, best mixed, $10 \mathrm{c}$.

Fringed.-Large fringed varieties, $15 \mathrm{c}$.

Double Mixed.-All colors, $20 \mathrm{c}$.

Phlox.-Unequalled showy for bedding, all colors, $5 \mathrm{c}$.

Poppy.-Exceedingly showy annual, making a gorgeous display, fine mixed, $5 \mathrm{c}$; oz. $20 \mathrm{c}$.

Carnation Flowered.-Mixed, splendid large double, $5 \mathrm{c}$; oz. $15 \mathrm{c}$.

Mikado.-Double white fringed petals tipped with scarlet, jc.

Admiral.-See Novelty page.

Paeony Flowered.-All colors, mixed, $5 \mathrm{c}$.

The Shirley.-Beautiful light shades of white and pink, desirable, $10 \mathrm{c}$; oz. $30 \mathrm{c}$.

Tulip.-A magnificent species from Armenia, large flowers of dazzling scarlet, $10 \mathrm{c}$.

Scarlet.-A beautiful bright scarlet, う̌c.

White Swan.-Large double, pure white, 5c.

Mephisto.-Deep scarlet with violet spots, $5 \mathrm{c}$.

Pavonium (Peacock Poppy.) - Scarlet with black ring, $5 \mathrm{c}$.

Danebrog.-Single scarlet with white blotch on each petal, $5 \mathrm{c}$.

All the above varieties, mixed, כ̌c.

Ricinus.-(Castor Bean.) Large tropical plants, ornamental leaved, $5 \mathrm{c}$.

Salpiglossis.—Grandiflora finest mixed, 5c.

Salvia.-(Scarlet Sage.) An old time favorite red bedder, $10 \mathrm{c}$.

Scabisoa.-(Mourning Bride.) Oid time plant, but better and larger, choice mixed, $5 \mathrm{c}$.

Snowball, white extra, 5c.

Schizanthus.-Butterfly flower, 5c.

Snapdragon.-Mixed, $5 \mathrm{c}$.

WHY USE A TEN YEAR NAIL FOR LAYING

THIRTY YEAR SHINGLE?

Send postal for samples, prices and particulars of the

\section{“M. I. F. CO. ZINC COATED" BRAND OF IRON CUT NAILS.}

They will last a lifetime.

MALLEABLE IRON FITTINGS CO., Branford, Conn. 
Silene.-(Catchfly.) A beautiful genus of profuse flowering plants, with bright and attractive flowers, mixed, 5 c.

Stock.-German ten-weeks, double, fine mixed, $10 \mathrm{c}$.

sweet William.-A well known and popular favorite. Hardy biennial, כ̄c.

Venus Looking Glass.-Finest mixed free flowering hardy annual, biooming the entire season, Ј̄c.

Verbena.-Finest mixed, a splendid strain, $10 \mathrm{c}$. Violets.-Blue, sweet, $10 \mathrm{c}$.

Viscaria.-(Rose of Heaven.) $5 c$.
Wild Cucumber.-(Creeping Jennie.) A rapid climber, $5 \mathrm{c}$.

Xeranthemum.- Showy everlasting flowers, Јc.

Zinnia.-Always popular, easily grown, brilliant display all summer, choicest double mixed, $5 \mathrm{c}$.

Dwarf Mixed.-Large nowering, jc.

Single Mixed.-All colors, ǰc.

Giant or Robusta.-Extra large, beautiful double flowers in great variety of colors, $10 \mathrm{c}$.

Zea.-Striped leaves, ornamental foliage, jc.

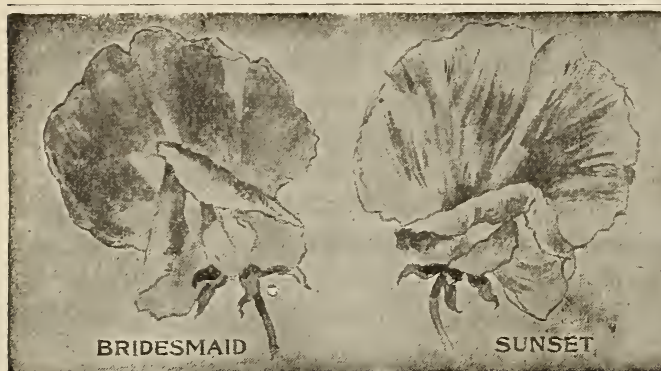

We are Headquarters for Sweet Peas.

We have grown and selected most of the rarieties ourselves and are thus in a position to deal generously with our patrons.

PRICES OF ALL THE FOLLOWING VARIETIES.—Packet, 5c; oz. 10c; 1-4 1b. 25c; unless otherwise noted.

Choice Mixed.-This mixture is made by ourselves and consists only of the choicest sorts, new and old in just the right proportion to make the most brilliant show. Pkt. je; oz. $10 \mathrm{c} ; 1-4$ 1b. $20 \mathrm{c}$; lb. $50 \mathrm{c}$; postpaid.

New Sweet Peas Mixed.-This is our own mixture of many distinct varieties. We can recommend it as a fine strain. Pkt. 5c; oz. $10 \mathrm{c} ; 1-4$ lb. $20 \mathrm{c} ; 1-2$ lb. $30 \mathrm{c}$; lb. 50 0 ; postpaid.

Eckford's Finest Mixed.-Includes the newest and best large flowering varieties of the most beautiful shades and colors. Pkt. 5c; oz. 10c; 1-4 lb. 25c; 1-2 lb. $40 \mathrm{c} ; 1 \mathrm{~b} .75 \mathrm{c}$.

American Beauties. - This mixture contains only grand, new named varieties of the large flowering type, highly recommended. Plit. $5 \mathrm{c} ;$ oz. $10 \mathrm{c} ; 1-4$ lb. $25 \mathrm{c} ; 1 \mathrm{~b} .75 \mathrm{c}$.

Our Gilt Edge or Invincible Mixture.-This is an up-to-date mixture of sweet peas and contains only grand, new varieties of the large flowering type, embracing a fine assortment of novelties. Pkt. $10 \mathrm{c}$; oz. $15 \mathrm{c}$; 2 oz. 25c; 1-4 lb. 30c; 1b. $\$ 1$, postpaid.

Spencer Mixture.-A mixture of the Spencel type large fluted flowers, in light shades plit. $10 \mathrm{c} ;$ oz. $20 \mathrm{c}$.
Double Mixed.-All varieties of double Sweet Peas mixed. Pkt. 5c; oz. 10c.

Rainbow Mixture. - Best mixture obtainable, all new varieties are included in this mixture. Large pkt. 10c; oz. 15̄c; 1-4 lb. 35c; lb. $\$ 1.25$.

Cupid Mixed.-All colors, 5̄c; oz. 10c.

Snapdragon Mixed.-All colors, 5c.

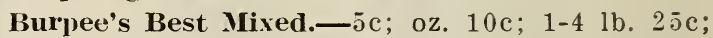
1b. $65 \mathrm{c}$.

Collection of 7 distinct varieties, 2 ãc.

Collection of 10 distinct varieties, $30 \mathrm{c}$.

Collection 25 varieties, $75 \mathrm{c}$.

Alba Magnifica, pure white.

America, the brightest blood red striped.

Apple Blossoms, bright rose and pink.

Blanche Burpee, New Giant White, finest white. Blanche Ferry, extra early, earliest sweet pea in cultivation.

Boreatton, dark, maroon.

Blushing Beauty, delicate, soft pink.

Brilliant, a very brilliant, rich red.

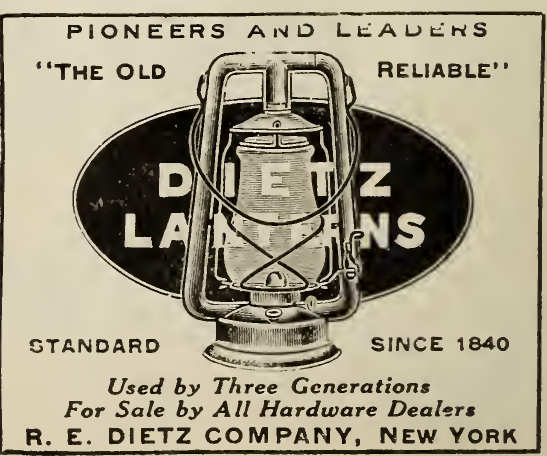


Cardinal, shining crimson-scarlet.

Countess of Radnor, delicate lavender.

Captain of the Blues, the nearest approach to blue.

Cupid, the new Dwarf Sweet Pea, white, pkt. こ̄c; pink, pkt. 5c; mixed, $5 \mathrm{c}$.

Dorothy Fckford, best pure white.

Dorothy Temmant, rosy heliotrope.

Earliest of All. In full bloom two weeks earlier than any other variety.

Emily Henderson, a fine new, absolutely pure white, early and free flowering.

Emily Erkford, Reddish mauve.

Fascination, new magenta-mauve.

Firefly. The most brilliant variety yet produced.

Gray Friar, delicate mauve, tinted with a darker shade.

Golden Gleam, a delicate primrose.

Golden Rose. Primrose yellow striped with pink. Pkt. $10 \mathrm{c} ;$ oz. $15 \mathrm{c}$.

Harvard, a deep crimson.

Imperial White, pure white.

Invincible Carmine, the flowers are of an intense shining crimson-scarlet.

liatherine Tracey (new,) a beautiful soft pink, flowers, large and perfect form.

Iing Edward VII. Best scarlet.

Lottie Eckford. Lavender blue.

Lady Hamilton, Best Lavender. Oz. $15 \mathrm{c}$.

Lovely, soft shell pink, a grand flower.

Mont Blanc, best white, very early.

Navy Blue, a large size, deep blue.

New Countess, a beautiful shade of lavender.

Othello, deep glossy maroon.

Olympia, soft pink, best in cultivation, $10 \mathrm{c}$.

Mars, new, bright, scarlet.

Mrs. Eckford, primrose-yellow.

Irs. Jos. Chamberlain, a large shell-shaped flower, striped and shaded with bright rose.

Mrs. Gladstone, a lovely soft pink.

Primrose, pale primrose yellow color.

Painted Lady, rose and white.

Princess May, very light lavender.

Prima Donna, best light pink.

Prince of Wales, deep rose.

Queen of England, grand, pure white.

Ramona, creamy white, daintly splashed with pale pink.

Red Riding Hood, a decided novelty. The standards in this variety are formed like a hood over the wings, very odd and curious.

Sadie Burpee, white, large hooded flower.

Senator, shaded striped chocolate.

Stanley, rich dark maroon.

Solopian, the finest scarlet.

The Bride, a fine large, pure white. Oz. $15 \mathrm{c}$. Wild Rose, best deep rose, pkt. $10 \mathrm{c}$; oz. $30 \mathrm{c}$.
Except where otherwise priced all the above are 5c. per packet, $10 \mathrm{c}$. per ounce, 25c. pel quarter pound.

\section{FOR NEW VARIETIES SEF NOVEITILA.}

\section{Wild Garden Mixed Flower Seed}

A splendid mixture of over one hundred rarieties of beautiful, free-blooming, hardy flowers, which can be offered at a much less price than when sold in separate packages. When flowering commences something new blooms almost daily. Extra large packages, 10c; 1-2 oz. 15 c.; oz. $25 \mathrm{c} ; 1-4$ lb. $50 \mathrm{c}$.

\section{Gladiolus Bulbs}

Fine Mixed, 3c. each; per 'doz. $30 \mathrm{c}$. Extra Mixed, 5c. each; per doz. $45 \mathrm{c}$.

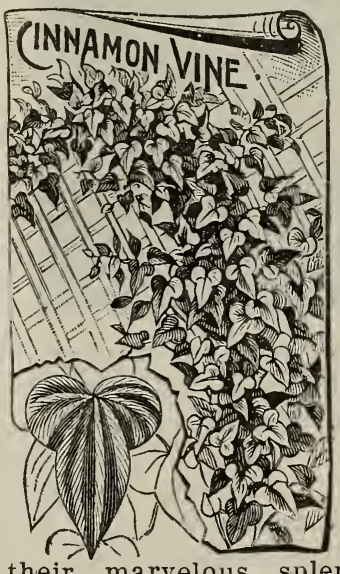

Cinnamon Vine.-From the Oriental land, is one of the most charming climbers. Beautiful, hardy climbers. Beautiful, hardy and very fragrant. Grows in sun or shade, wet or dry. Can be grown in the house in the winter. Everyone should plant these lovely vines. No home is complete without them. They stand the hardest winter without injury, and burst forth in all their marvelous splendor very early in the spring-as fine a climber as any lover of beautiful flowers can wish.

Postpaid, 5c. each, 6 for $25 \mathrm{c}$.

\section{Dutch Bulbs for Fall Planting}

Ready in September.

$\mathrm{P}^{1}$ ant in the garden from October to December, the earlier the better, also for pot culture for winter blooming.

\section{Everlasting Flowers}

The Everlasting Flowers, with their rich, brilliant colors, are very valuable for winter decorations. They should be cut as soon as they come into full bloom, tied in small bunches, and dried slowly in the shade. Choice mixed, large package, $10 \mathrm{c}$.

ESTABLISHED 1818

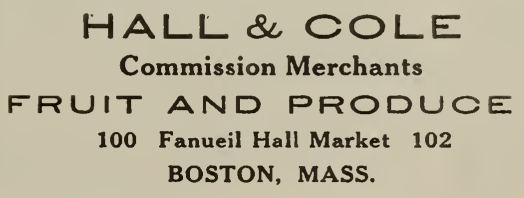

STACY HALL

STACY L. HALL 


\section{Dahlias}

Will grow in any kind of soil and give continuous bloom from July till after frost. Ours are from finest named sorts Show, Decorative, Pompon, and Single varieties $12 \mathrm{c}$. each, postpaid. Cactus, $15 \mathrm{c}$. , postpaid.

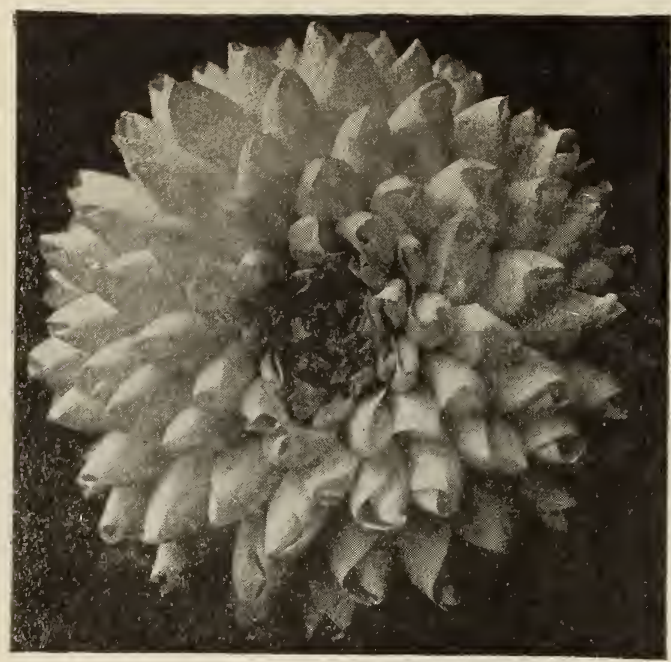

Special Offer, one that will please you, 5 for $50 \mathrm{c} ; 12$ for $\$ 1.00 ; 25$ for $\$ 1.75$. The selection to be left to us, the purchaser paying express charges.

\section{Hardy, Ornamental Plants}

sent direct to any address, postpaid.

IV send out all plants during the first mild weather. The climbing vines, flowering shrubs, and fruit plants must be sent out while in a dormant condition. Orders for these items, therefore, should reach us by the middle of April at the latest. Orders for roses and greenhouse plants can be filled up to first of June.

\section{ROSES-Hardy Perpetual Roses}

Order's filled to June 1 st.

Price of any Rose except otherwise stated $12 \mathrm{c}$ each 3 for $30 \mathrm{c}$., postpaid.

Anerican Beatuty-Rich, rosy crimson.

Alfred Colcomb.-Bright crimson.

Caprice.-Pink striped with white and carmince. Anne Deisbach.-Brilliant shell pink.

Gen. Jacqueminot.-Rich crimson scarlet.

Gen. Washington.-Soft, glossy scarlet.

Marshall P. Wilker.-Very fragrant crimson.

Magua Charta.-Clear, rosy red.

Mue. Plantier.-Pure white.

John lieynes._Fine deep maroon.

Croquette de Alps.-Pure white, tinged pink.

Helen Keller.-(New). Color brilliant cerise.

\section{Ever-Blooming Bedding Roses}

IBon Silene.-Color deep rose.

Bride.-White tea rose.

Bridesmaid.-Fine, clean pink.

Clotilde Soupert.-Blush white.

Pink Soupert.-A beautiful pink.

Yellow Soupert.-Pale Yellow.

Perle des Jardins.-Clear, golden yellow.

White La France lRed La France

Pink La France striped La France

\section{Japanese Rambler Roses}

Most charming of all climbing Roses, hardy and vigorous making shoots of 15 to 20 feet in one season.

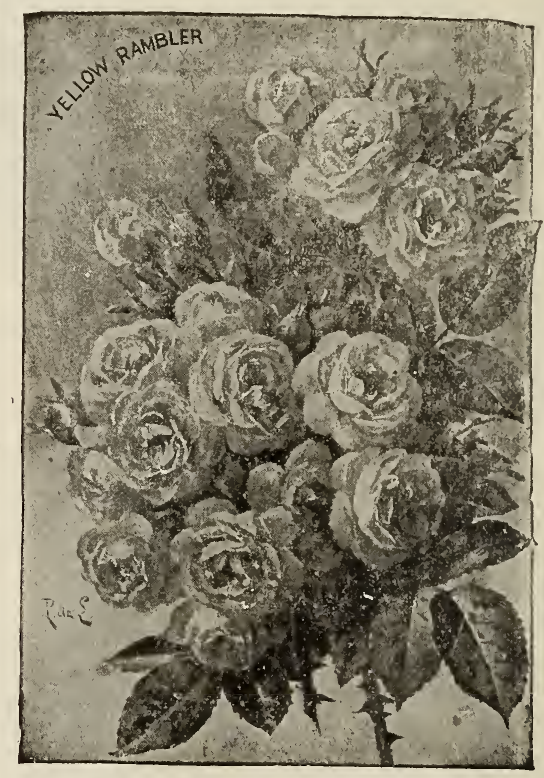

Crimson

Ramblex

Pink

Ramblei

Jellow

IRambler

White

Rambler

Price 1:cc each, 3 for 30c.

\section{JAPANESE RAMBLER ROSES}

\section{Baby Rambler Roses}

In bloom all the time The foliage is of a fine polished dark green, never attacked by insects. It blooms in clusters and is very continu. ous, of bushy compact growth, fine for pot cul ture. $15 \mathrm{c}$. each. Postpaid 2 for $25 \mathrm{c}$.

\section{Two New Climbing Roses}

Flower of Fairfield.-A perpetual blooming variety, producing repeated crops of bloom until late in the autumn brilliant crimson and a rapid grower.

Veilchenblan Blue Rose.-The flowers appear in large clusters, are semi double of medium size. Upon opening the color is a bright rose, soon changing to a steel blue. A strong grower with shining green foliage. Price, each of the above $18 \mathrm{c}$. or two for $35 \mathrm{c}$. 


\section{Moss Roses}

Blanche Moreau.-Pure white.

Crimson Globe.-A fine deep crimson.

Princess Adelaide.-Bright rosy pink.

Baltimore Belle

\section{Clımbing Roses}

Greville.

Empress of China

Iary Washington

borothy l'erkins.-The flowers are very double and of a beautiful shell pink color, very large and sweetly scented. Each 15c; 3 for $40 \mathrm{c}$, postpaid.

Price of any Rose except otherwise stater, 12. each; 3 for 30c.; postpaid.

\section{Clematis}

There is no more ornamental class of plants than Clematis. The flowers are of large size measuring four to six and sometimes eight inches in diameter.

Duchess of Ediuburg.-A fine double white. Henriji.-Large flowered, pure white.

Jackmanni.-Large flowers, rich violet.

Madame Baron Veillard.-A beautiful lavender pink.

Marlame Andre.-Very large flower, a pleasing shade of carmine.

Clematis Paniculata.-Very hardy, rapid grower, small white flowers, borne in great clusters.

Price 15c. each; 3 for $35 c .$, postpaid.

\section{Hardy Climbing Vines and Shrubs}

Orders filled up to April 20th.

Bleeding Heart Althea Spiria

Coreopses Snowball Japanese Iris

Passion Flower S;ringa Hydrangea

Honeysuckle Wisteria Moon Vine

Wigelia Hollyhocks English Ivy

Prices each 12c; 3 for 30 c., postpaid.

\section{Golden Glow}

This is one of the grandest hardy flowering plants ever introduced. Blooms during July and August the first season, and bears immense masses of large, round, golden vellow flowers. Price, $10 \mathrm{c}$. each; 3 for $25 \mathrm{c}$, postpaid. Large clumps by express 2 ว̌c.

\section{Hardy Perennial Phlox}

They are perfectly hardy, succeeding in any garden soil, and producing magnificent spikes of showy and lasting flowers.

Bright Red, Scarlet, White, Orange, Sa!mon, Pink, Rose, White with Crimson Eye. Price 1j̄. each; 3 for $40 \mathrm{c}$, postpaid.

\section{Hydrangea Paninculata Grandiflora}

One of the finest hardy shrubs ever produced, blooms from August to middle of October. Price $12 \mathrm{c}$. each; 3 for $30 \mathrm{c}$. , postpaid.

\section{Bedding and House Plants \\ Orders filled up to June 1 st.}

ASPARARGUS PLUMOSA or Climbing Lace Fern.-A graceful window climber, bright green foliage, with lovely spray-like fronds. Each 15c; 3 for 40 c., postpaid.

\section{Carilitions.}

Daybreak.-Salmon pink. Flora Hill-White. Eldorado.-Light yellow.

Gold Nuggett.-Deep yellow.

Mrs. Thomas Lawsol. - Enormous size a beautiful pink color. Price each, $10 \mathrm{c} ; 6$ for $50 \mathrm{c}$, postpaid.

\section{Coleus.}

Golden Bedder.-Golden yellow.

Fire Brand.-Shaded garnet.

Velchafeltii.-A rich velvet crimson.

Each, 12c; 3 for $30 \mathrm{c}$, postpaid.

\section{Cannas.}

Price, dormant roots, $15 \mathrm{c}$, each; 3 for $40 \mathrm{c}$. Can be furnished up to May 1st.

Lily of the Valley.

6 c. each; 6 for 30 c., postpaid.

Fuchsias

Single Geraniums

Double Geraniums

Chrysanthemums

Flowering Begonias

Abutilion

Price, each 12c; 3 for $30 c$; postpaid.

Lenon, American Wonder.-Very ornamental, edible fruit of immense size, a fine pot plant. $15 \mathrm{c}$. each.

The Roof That You Needn't Worry About

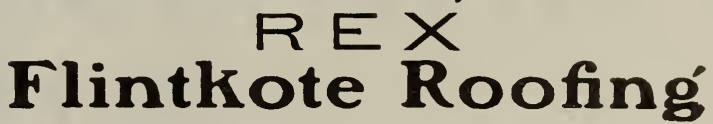

Peace of mind and a sense of security enjoyed by the man who has his buildings roofed with Rex Flintkote. He knows that water cannot get through it, winds cannot blow it off, falling sparks cannot ignite it.

\section{FREE SAMPLES}

Let us send you free samples to test; also valuable roofing booklet.

Be sure to "Look for the Boy."

\section{J. A. \& W. BIRD \& COMPANY} 34 India Street

Boston, - - Mass.

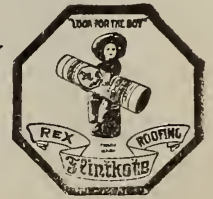


Orange Chinese Dwarf, a pot plant of great beauty. $15 \mathrm{c}$. each.

One Lemon and One Orange for 25̄c., postpaid.

Famous Boston Sword Ferns. 15c. each; 2 for $25 \mathrm{c}$.

Piex. Hegonias, large leaves, very ornamental. 15c. each; 3 for $40 \mathrm{c}$.

Burbank's Shasta Daisy, Giant Daisy succeeds anywhere. $12 \mathrm{c}$. each; 3 for $30 \mathrm{c}$.

Geraniums,

Clyde, best single scarlet.

Countess of Harcourt, large pure white.

Mrs. E. G. Hill, best single Salmon.

S. A. Nutt, best double crimson.

Jean Viand, immense flowers, a clear rosy pink. Rose, Scented, the foliage very fragrant.

Ivy-Leaved, a beautiful plant for the window.

Madame Bruant, large size white penciled with deep rose.

$12 \mathrm{c}$ each; 3 for $30 \mathrm{c}$.

Solanum, (Jerusalem Cherry), covered with bright scarlet cherries all winter. $12 \mathrm{c}$ each.

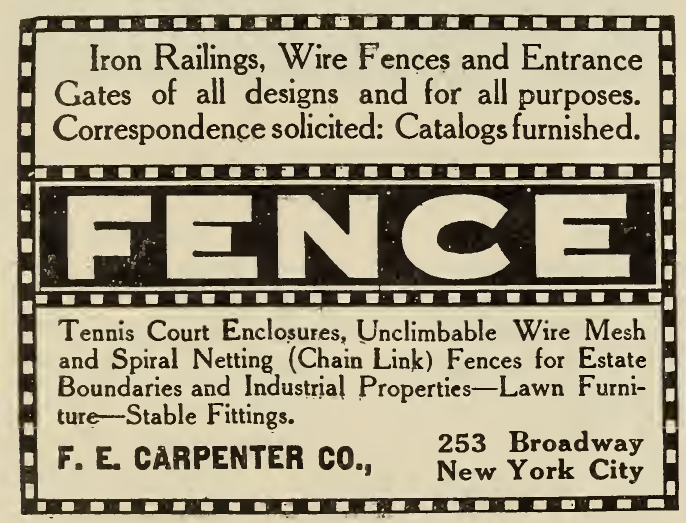

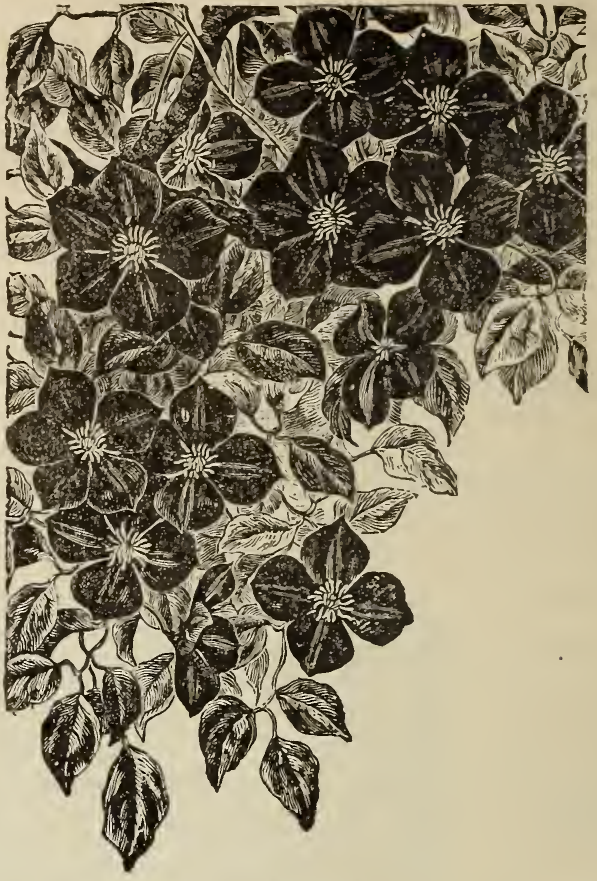

CLEMATIS

Portland, Maine, March, 1910.

I had by first experience with a garden last year and the Beefsteak Lettuce I raised was the talk of the town. I sowed the seed you sent me out doors and my lettuce grew fully as fast as that of others near me who transplanted.

The red shades in this variety make it fine for decorating and it eats as tender and crisp as any I ever tried.
F. S. MORTON,

Business Manager,

Portland Publishing Co.

\section{5,00O HOMES ARE HEATED BY \\ KELSEY $\underset{\text { AIR }}{\text { WARM GENERATORS }}$}

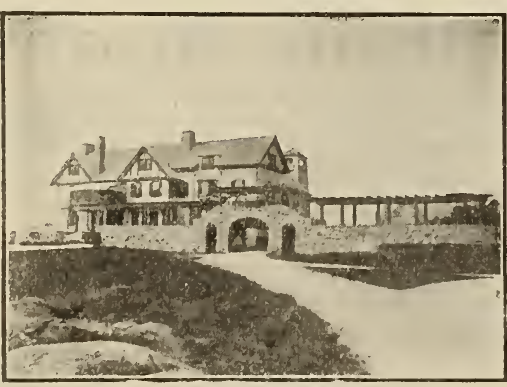

Kelsey Heated Country Residence of

Hon. K. B. TREat, Providence, R. I. Sold by 900 Dealers
20,000 are in New York and New England States. There's no other system of heating that is so healthful and economical and so easy to manage and no system that has been so highly endorsed by the users. Kelsey Heating is tle right kind of heating for small houses, for the finest class of city or country residences and for churches and schools.

Send for Booklet of Information and for 112 Page Book "OPINIONS" Free.

\section{TELSEY HEATING CO.}

Main Office-208 Rosenbloom Bld'g, Syracuse, N: $Y$. 


\section{WILLOWCRAFT}

is the only durable line of

\section{WILLOW FURNITURE}

made in the United States. We are the ma $11 \mathrm{ufacturers}$. and will send this sample chair for $\$ 7.75$, fgt. prepaid,

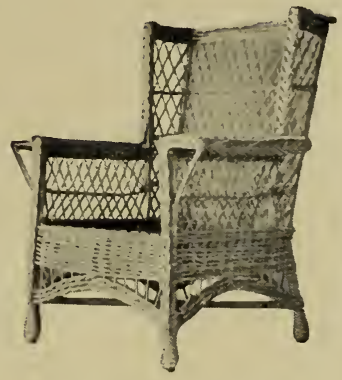
anywhere east of the Mississippi River. IVrite for our catalogue of 150 other patterns.

\section{The Willowcraft Shops}

Box M, North Cambridge, Mass.

\section{Sprayers}

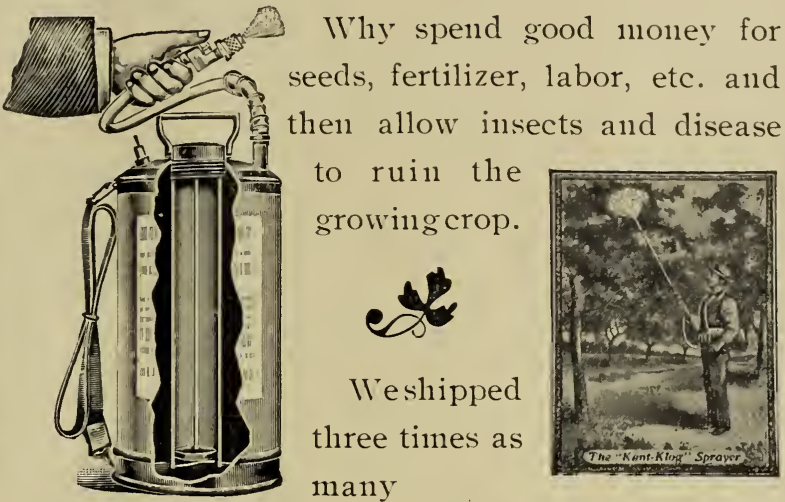

\section{“KANT CLOG" SPRAYERS}

to New England last season as we did the previous year.

Send your address for free Booklet, spraying guide, etc. Address

\section{ROCHESTER SPRAY PUMP CO.}

\section{East Ave., Rochester, New York}

\section{Sagadahoc

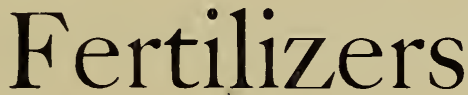

9 BRANIS

\section{Special Brands for Potatoes}

Use our new 6-6 \& 6 Brand for Potatoes.

The Dirigo Fertilizer for hay and grain lasts in the soil.

SAGADAHOC FERTILIZER CO. BOWDOINHAM, - MAINE

W. B. KENDALL, Manager

\section{A REMARKABLE CROP OF PEAS.}

Richmond, Maine, Dec. 4, 1909.

Mr. Kimball,

Dear Sir:

You requested me to give you my success with the peck of Notts Excelsior Peas that you shipped me the first of July. Will say that I planted them the 6 th day of July, the $26 \mathrm{th}$ of August we had our first mess of peas from them. We had all the peas we wanted until the first of October. We had 8 in the family all of the time. We canned 50 quarts. It was so dry I didn't expect they would do very much but I never had a piece of peas pod better or hold green longer. I think they are the very best pea to plant for a late pea that I ever tried.

The vines are small they are almost proof against mildew, which will spoil all rank growing peas that I ever tried.

\section{Mode of Cultivation.}

I planted them on land that was planted last year and dressed. I planted with King of Corn Field Planter, rows 30 inches apart drilled quite thick with liberal dose of Sagadahoc Corn Fertilizer, then kept the ground loose and weeds out.

\section{Fraternally,}

DANIEL BROWN,

R. F. D. 13, Gardiner. 



\section{THE MAGAZINE FOR THE COUNTRY HOME-THE}

HOUSE \& GARDEN shows in picture and text all that is best in house building, furnishing and interior decoration. In strong, readable articles, by men who know their subjects and who are authorities on what they write, the various architectural styles are pictured and described-Colonial, English Half-timber, Cement, Stucco, Tudor, Mission, Bungalow, etc. All the ramifications of the subject are taken up in articles which will delight and help every home-maker the various rooms of the house, hallways, stairways, chimneys, fireplaces, porches, windows, entrances, outdoor sleeping and living rooms, wall coverings, rugs, curtains, pictures, draperies, antique furniture and furnishings, and the innumerable things about the house in which every home owner is interested. The articles are superbly illustrated by the finest half-tone engravings.

\section{HOUSE AND THE GARDEN}

The surroundings of the house are as important as the interior for comfort and beauty, and HOUSE \& GARDEN deals adequately with this delightful side of country living. Its treatment of the subject is essentially practical, is of interest alike to the beginner or advanced gardener and for the small plot as well as for the large estate. It covers every phase of the subject from window-boxes to landscaping: The vegetable garden, the flower garden, the fruit garden, bulbs, shrubs, trees, hardy flowers, hedges, vines and trailers, the lawn, the water garden, the rock garden, hotbeds, coldframes, the greenhouse, fertilizers, insecticides and the thousand and one things that demand the interest and attention of every garden-maker. There is even a Beginner's Department which deals with first principles from which the most inexperienced can work.

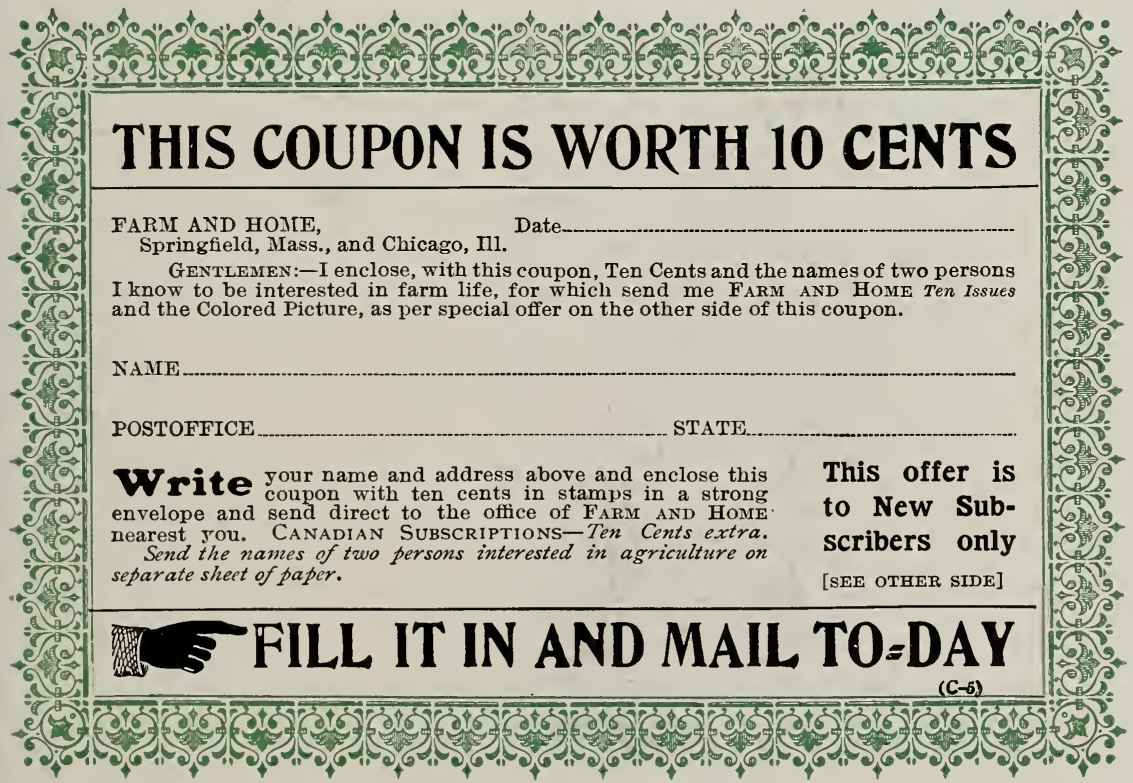




\section{SIX BEAUTIFUL MAGAZINES FOR $\$ 1.00$}

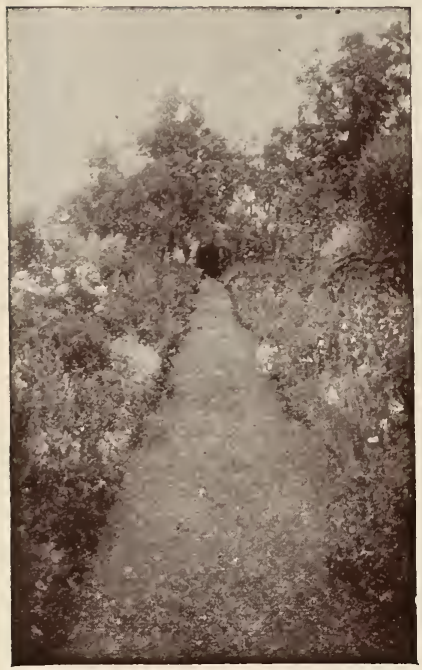

HOUSE \& GARDEN, enlarged and greatly improved, is the authoritative guide in all matters relating to the house and to the garden. We are glad to direct the attention of our patrons to this aid to intelligent garden making, since far better results in growing bulbs, plants and seeds will be secured if their planting and culture be carefully directed.

The issues for the next six months will be full of notable articles on the home, its building and furnishing, and its surroundings. The April number will be a splendid Spring Gardening Annual especially devoted to the garden and its work, - this issue alone will be of invaluable service to those interested in the beauty and utility of the garden. The subscription price of HOUSE \& GARDEN is \$3. a year, but the publishers have made a Special Rate to our patrons so they may get the magazine for six months for $\$ \mathrm{r}$., which includes all the important gardening issues of the Spring and early Summer.

... . . . . . . . . . . . Use this Coupon. . . . . . . . . . . . . PINE TREE STATE SEED CO,

\section{Bath, Niaine.}

Please instruct Messrs. McBride, Winston \& Co. to send me HOUSE \& GARDEN for six months. I enclose \$I.

\section{Name}

\section{Address}

\section{A SPECIAL OFFER}

TO OUR CUSTOMERS

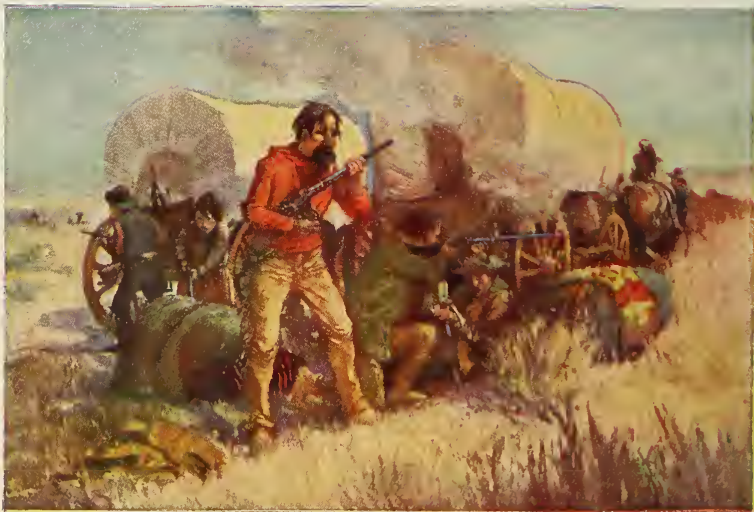

"THE PIONEERS" Overflowing with action and sentiment, ThE PIONEERS, this subject vividly depicting the dangers and diffculties of our forefathers in settling the Westan ardent attempt to save the lives of their dear ones-will appeal forcibly to every liberty-loving man, woman and child.

\section{HOW TO GET H $\mathrm{H}$ THS $\mathrm{H}$}

By special arrangements with FARY AXip HOYE, which wo can recommend as the very best farm and family seml-monthiy published, we aro enabled to offer you-although the regular price is 50 centy per year-a trial subseription of ten issues for only 10 cents lu coin or stamps, if accompanied by this coupon.

Furthermore, If you will send at the same time dlrect to the publishers, the addresses of two other persons tuterested in furm life, they will send you the beautiful colored picture here illustrated, printed on heary paper. size $10 \times 15$ inches, suitable for framing.

This is certainly an exceptional opportunity and you should not fail to take advantage of it. But be sure and use this coupon, flling in the other side (this coupon is worth 10 cents to you). 


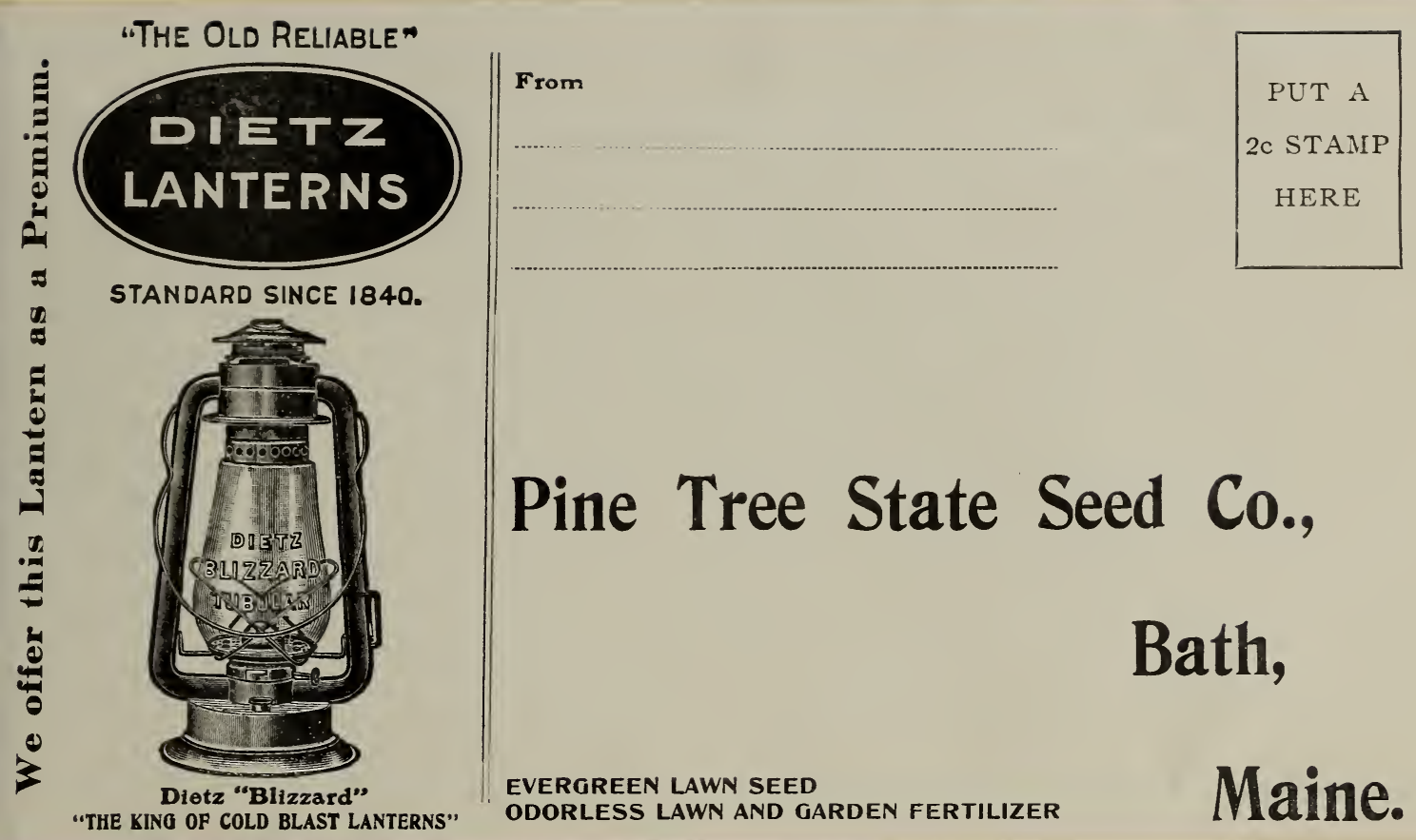

\section{SAFETY MONEY BAG}

For Coin, Stamps, Bills, Checks and Money Orders.

Convenient and safe to send through the mail with your order for seeds.

Return this envelope with your order and we will send you FREE a packet of any of the following:

Mixed Cabbage

Dirigo Beet

May King Lettuce

Prize Head Lettuce

Dewey Tomato

White Rice Pop Corn

White Icicle Radish
Giant Zinnia

Giant Marigold

Royal Show Aster

Gilt Edge Mixed Sweet Pea

Poppy, all kinds mixed

Morning Glory, 12 colors

Mixed Flower Seeds, 100 varieties

Place an $\mathrm{X}$ in front of packet wanted.

\section{PINE TREE STATE SEED CO. BATH, MAINE}


AVOID ALL RISKS

\section{BY USING}

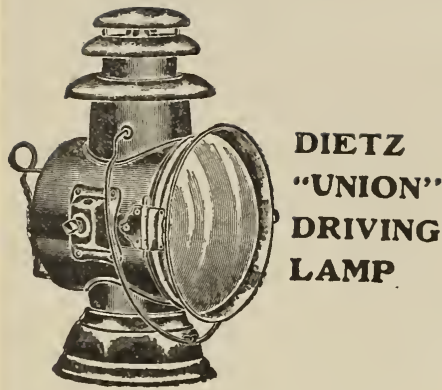

DIETZ

"VICTOR"

LANTERN
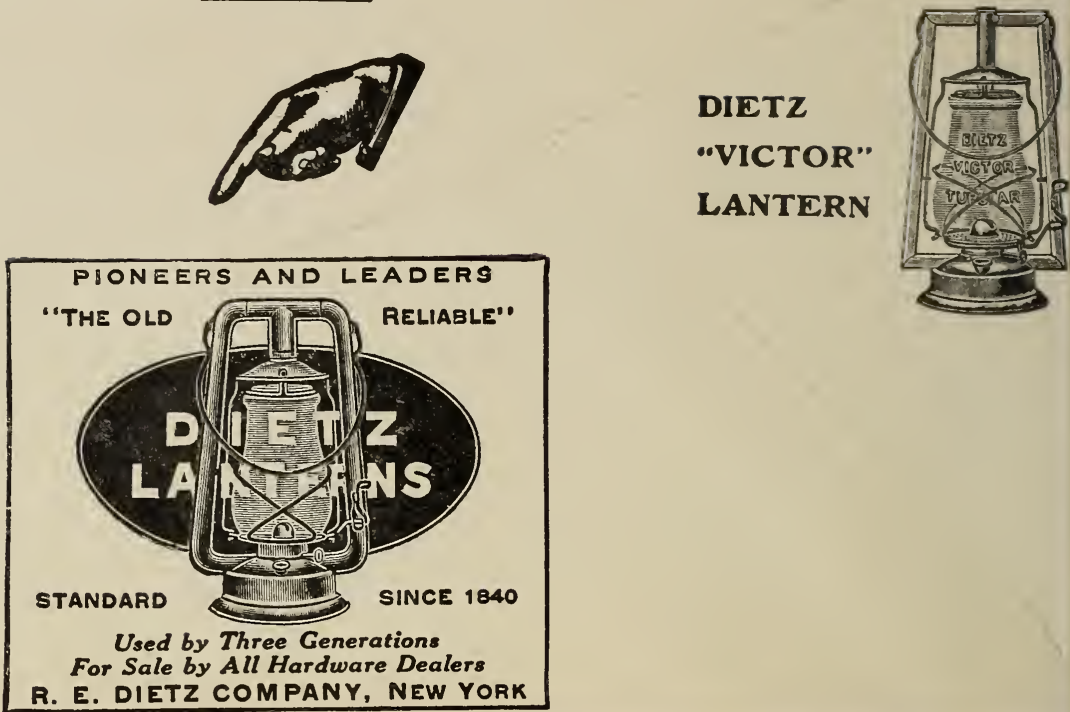
To our Customers:

We are so impressed with the February issue of The Garden lagazine which we have just finishod reading, that we would like to devise a plan that would make all of our customers subscribe to it.

This magazine has been good from the beginning and is getting better all the time. Today it is by far the hest gardening periodical in the world and worth much more than a dollar to the owmer of the smallest or largest garden.

Our recommendation should induce every one of our customers to subscribe, but it won't, so we have persuaded our company to make the following offer:

Every customer who sends an order for \$2. may add a subscription to The Garden Nagazine for six months or for 4 orders a subscription for one year.

The customer who receives The Garden liagazine vil]. be a belter one - easier to do business with, becauss he will get better results. So it is plain that we do not make this offer for philanthropic purposes.

The illustrations are alone worth the price. a delight and an education. Articles on cultural directions are real directions, written by real gardeners who know how to write.

Perhaps you are not going to send us an order this year. If not, write your name and address on the margin of this sheet and send it with the dollar, direct to Doubleday, Page \& Company, 137 East 16th Street, New York. We are sure you will thank us for the suggestion before another season passes.

Yours very truly,

Pine Tree State Seed Company.

\section{PINE TREE STATE SEED COMPANY, BATH, MAINE}

State here whether wanted by

MAIL, EXPRESS, OR FREIGHT

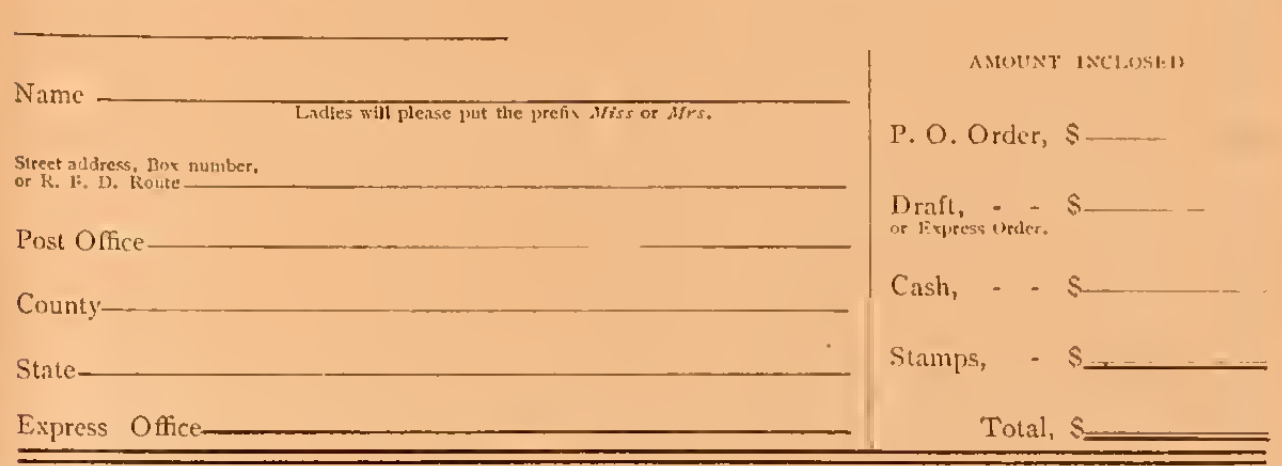

If SEEDS POSTPAID, BY MAIL. Wc send all Flower and Vegctable Sceds by the pracket, ounce and quarter ponnd postpaid by mail. I BY THE QUART our prices do not include postage. If quarts are ordered to be sent by mail, 15 cents per quert on Peas and lieans and to cents per quart on Sweet Corn must be remitted in addition to cuver actual cost of postage. 1 PREMUNIS. On Seeds in packets and ounces the purchaser can selert 2.5 cents' worth of packets and ounces extra for cach one dollar's worth of packets and ounces ordereil.

- SPACE FOR YOUR REMARKS. Below you will kindly give us any special instructions concerning vour order. Also the names and addresses of a few of your friends who itre interested in growing flowers or vegetables. 


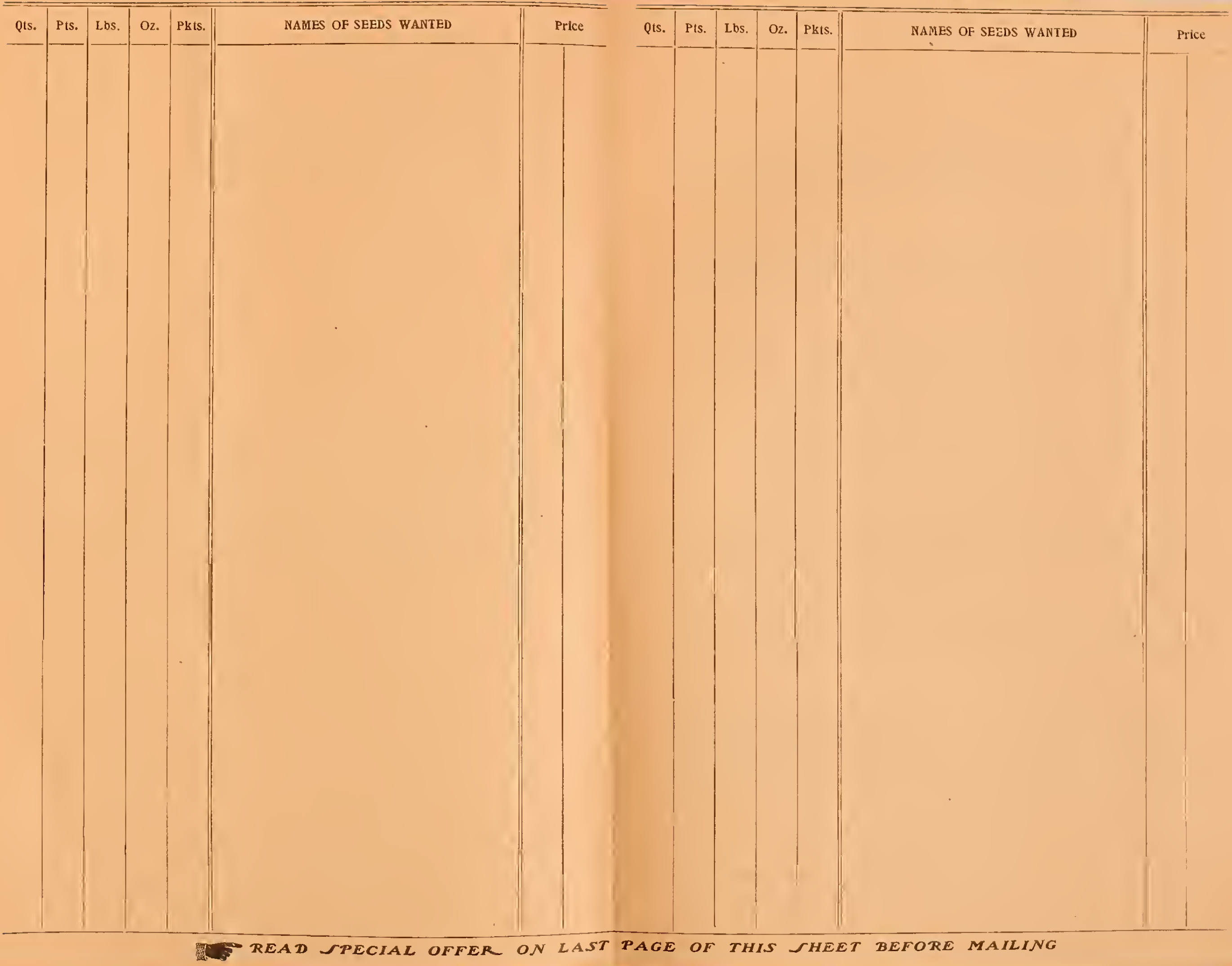




\section{Pine Tree State Seed Co.}
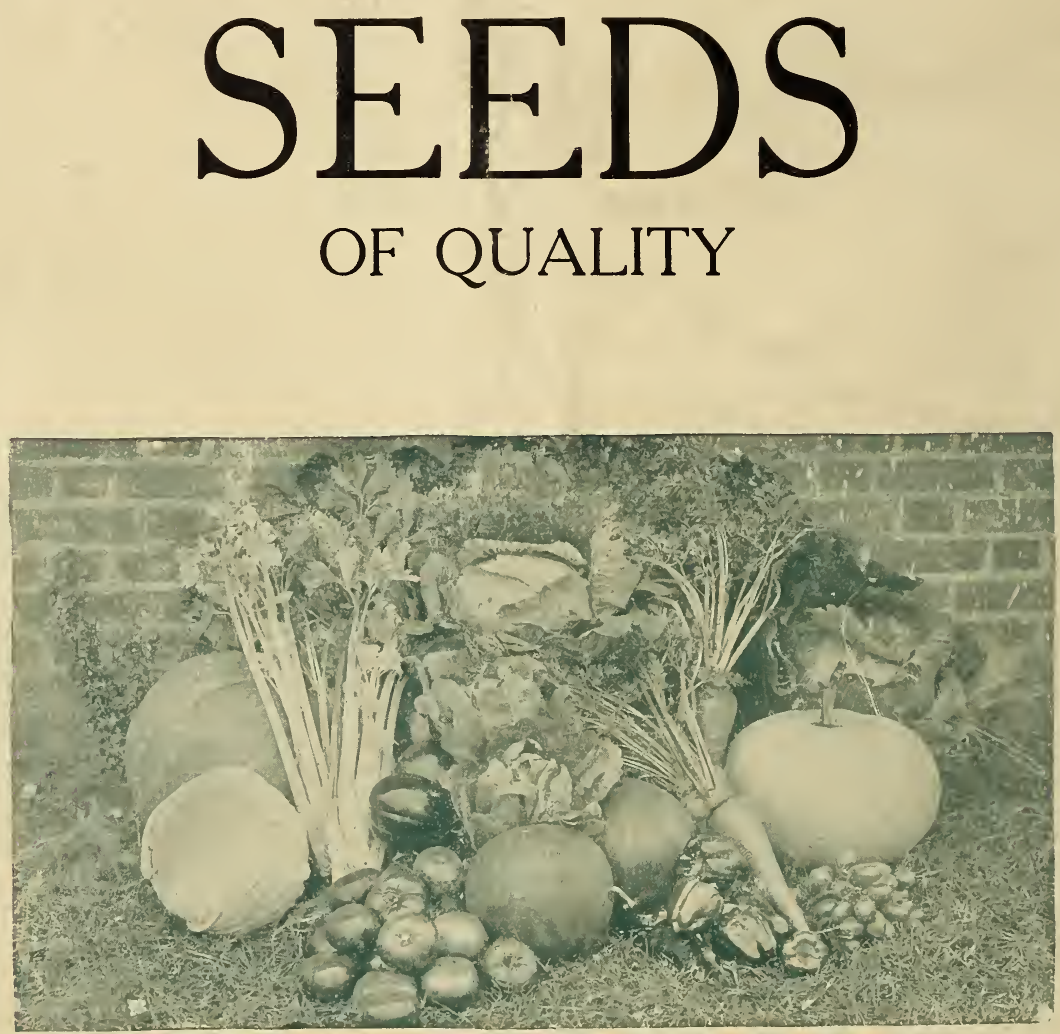

Best For New England

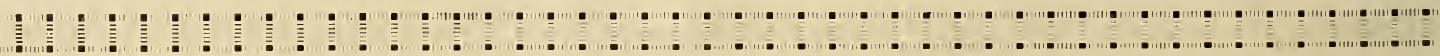

BATH, "PINE TREE STATE" 